\title{
ULUSLARARASI ANDLAŞMALARI AKDETME VE ONAYLAMA YETKISI
}

\author{
(Bir Karşılaşıırmalı Anayasa Hukuku Incelemesi)
}

\author{
Doç. Dr. Kemal Gözler \\ Uludag Úniversitesi \\ Iktisadi ve Idari Bilimler Fakulltesi
}

\section{Ōzet}

Bu makalede, yirmi iki ülkenin anayasal düzenlemelerinden hareketle, uluslararası andlaşmalan akdetme ve onaylama yetkisi karşlaşturmalı olarak incelenmektedir. Incelediğimiz ülkelerin hepsinde, uluslararası andlaşmalan akdetme yetkisi, parlâmentolara değil, yürütme organına (devlet başkanına veya hükûmete) verilmiştir. Incelediğimiz ülkelerin üçünde uluslararası andlaşmaları onaylama yetkisini doğrudan parlàmentolara, on beşinde devlet başkanlanna ve üçünde de hükûmetlere aittir. Onaylama yetkisinin devlet başkanlanna veya hükûmetlere verildiğgi ülkelerin hepsinde, bu yetkinin kullanılabilmesi için, uluslararası andlaşmalarnn hepsinin veya bir kısmunun parlâmento tarafindan uygun bulunması gerekmektedir. Akdetme veya onay yetkisinin devlet başkanına verildiği ülkelerin hepsinde devlet başkanının bu yetkileri kar̨̧ı-imza kuralına tâbi tutulmuştur. Incelediğimiz ülkelerin altusında parlàmentonun bazı andlaşmalan uygun bulabilmesi için 2/3 gibi özel karar yetersayısı gerekmektedir. Dört ülkede ise anayasaya aykın andlaşmaların onaylanabilmesi için ya anayasada değişiklik yapılması ya da anayasaya aykın olan uluslararası andlaşmanun parlâmentonun nitelikli çoğunluğu tarafından kabul edilmesi şarttur.

\section{The Power to Conclude and Ratify International Treaties: A Comparative Constitutional Law Study \\ Abstract}

This article examines the power to conclude and ratify international treaties from the comparative point of view on the basis of constitutional stipulations of twenty-two countries. In all these countries, the power to conclude international treaties belongs, not to the parliaments, but to the executive bodies (head of state or government). The power to ratify international treaties is attributed to the parliaments in three of the countries examined, to the heads of state in fifteen of them and to the governments in three. In these countries, before the ratification, the prior approval of the parliament is required for all or certain treaties. In all of the countries in which the power to conclude to ratify treaties belongs to the head of state, these powers are subject to countersignature rule. In six countries, qualified majority (e.g. $2 / 3$ ) of the votes cast in the parliament is necessary for the approval of treaties. In four countries, for the ratification of an international treaty which contains the stipulations contrary to constitution, a prior constitutional revision or the approval of the parliament by a qualified majority of the votes cast is required. 


\section{Uluslararası Andlaşmaları Akdetme ve , Onaylama Yetkisi (Bir Karşlaştırmalı Anayasa Hukuku İncelemesi)}

Uluslararası hukukun en önemli kaynağı "andlaşmalar (treaties, traités)"dır. Andlaşmalar, "ahde vefa (pacta sunt servanda)" ilkesi gereği taraf devletleri bağlar. Keza andlaşmalar, aynı zamanda iç hukuk bakımından da bağlayıc işlemlerdir. Bu önemleri nedeniyle, uluslararası andlaşma yapma yetkisine ilişkin bazı konular anayasalar tarafından düzenlemektedir. Biz de burada bu düzenlemelerin karşılaştırmalı bir incelemesini yapmaya çalışacağız.

Bu incelememiz için yirmi iki ülkenin anayasalann veri olarak ele aldık. Bu yirmi iki ülke şu şckilde seçilmiştir: tlk olarak Arend Lijphart'ın demokratik olarak kabul ettiği yirmidört ülke ele alınmuştır. Bu ülkeler şunlardır: Almanya, Amerika Birleşik Devletleri, Avustralya, Avusturya, Belçika, Danimarka, Finlandiya, Fransa, Hollanda, Ingiltere, Irlanda, Ispanya, Israil, Isvec, Isviçre, Italya, Izlanda, Japonya, Kanada, Lüksemburg, Norvec, Portekiz, Yeni Zelanda, Yunanistan. Bu ülkelerin ortak özellikleri, bunlardaki demokratik rejimlerin az çok uzunca bir zamandan beri kesintisiz olarak sürmüş olmasıdır (LIJPHART, Tarihsiz: 11-13, 36-43). Bu ülkelerden Avustralya, Kanada ve Yeni Zelanda'yı çalışmamızın dışında tuttuk. Zira bu üç ülkenin anayasalanında uluslararası andlaşma yapma yetkisine ilişkin bir hüküm bulamadık. Geri kalan yirmi bir ülkeye Türkiye'yi de ilâve ettik. Böylece yirmi iki ülkelik bir liste oluşturduk ${ }^{1}$.

Anayasalar, uluslararası andlaşma yapma yetkisini genellikle "akdetme (conclusion)" yetkisi ve "onay (ratification)" yetkisi olmak üzere ikiye ayırıp düzenlenmektedir. Biz de burada andlaşma yapma yetkisini "akdetme yetkisi" ve "onay yetkisi" olmak üzere ikiye ayınp inceleyeceğiz.

1 Bu ülkeler şunlardır. A.B.D., Almanya, Avusturya, Belçika, Danimarka, Finlandiya, Fransa, Hollanda, Ingiltere, Irlanda, Ispanya, Israil Isviçre, Italya, Izlanda, Japonya, Lüksemburg, Norvec, Portekiz, Türkiye, Yunanistan. 


\section{AKDETME YETKISI}

Andlaşmaların akdedilmesi, "görüşme (negotiation, négociation)", "anlaşma metninin yazılması" ve metnin "imzalanması (signature)" safhaların içerir (PAZARCI, 1998: 115; CARREAU, 1988: 112-117; BROWNLIE, 1996: 605-607). Andlaşma akdetme yetkisine sahip kişiler, devlet adına görüşmelere katılırlar. Karşlıklı görüşmeler neticesinde bir "andlaşma metni" hazırlanur. Bu metne, onun "mevsukiyet (authentification)"ini sağlamak amacıyla, görüşmeci taraflar "imza (signature)" koyarlar veya daha sonra "imza" koymak üzere sadece "paraf (paraphe)" atarlar (PACTET, 1994: 121-122; BROWNLIE, 1996: 606; CARREAU, 1988: 114-115). Bu işlemlerden sonra aşağıda göreceğimiz "onay" safhasına geçilir.

Bir devlette, devlet adına başka devletler ile andlaşma akdetme yetkisinin parlâmentolara değil, yürütme organuna ait olduğu kabul edilmektedir (GREWE / RUIZ FABRI, 1995: 104). 1969 Viyana Andlaşmalar Hukuku Sözleşmesi, bir devlet adına andlaşma yapmaya yetkili kişileri iki gruba ayırarak düzenlemektedir (m.7). Bunlardan birinci grubu, özel bir yetki belgesine gerek olmadan, andlaşma yapma genel yetkisine sahip olan kişilerdir. Bu kişiler dışişleri bakanlan, hükamet başkanlan ve devlet başkanlandır (m.7/2-a). Andlaşma akdetme yetkisine sahip ikinci grup kişiler ise, andlaşma akdetmek için "tam yetki belgesi (lettre de pleins pouvoirs)" ismi verilen özel bir belge ile yetkilendirilen kişilerdir. Bunlara "tam yetkili temsilciler (plenipotentiaries, plénipotentiaires)" denir. Bu kişiler de, parlamento tarafından değil, yürütme organı (dışişleri bakan, başbakan veya devlet başkan) tarafından yetkilendirilirler (BARTHÉLEMY / DUEZ, 1933: 834; DE SMITH / BRAZIER, 1989: 140; PACTET, 1994: 502; PAZARCI, 1998: 121-122).

Andlaşmaların akdedilmesi safhasında bütün yetki münhasıran yürütme organına aittir. Parlámentonun andlaşmaların yapılması safhasına katılması mümkün değildir. Keza parlâmentonun andlaşmaların akdedilmesi safhasına ilişkin olarak yürütme organın denetlemesi de söz konusu olamaz. Zira, görüşme safhası esas itibarnyla gizlidir (HOOD PHILLIPS / JACKSON, 1987: 287). Bu safhada parlâmentoda yapılan görüşmeler ile ilgili soru sorulması, genel görüşme açlmasınun mümkün olmaması gerekir. Zira bu sorulara yanut verilmesi durumunda yapılacak andlaşma tehlikeye düşer. Nihayet görüşme safhası, diplomatik pazarlık safhasıdır. Kartları açı̆̆a çıkmış taraf bu pazarlığı kaybeder (BARTHÉLEMY / DUEZ, 1933: 828). Bununla birlikte, kanumızca, parlammentonun arzu etmediği bir ülke ile uygun bulmadığı bir konuda anlaşma yapmak üzere görüşmelere başlayan hükameti, parlâmento gensoru veya güvensizlik oyu verip düşürebilir. 


\section{A. ANAYASAL dÜZEMLEMELER}

Şimdi uluslararası andlaşma akdetme yetkisi konusunda çeşitli ülkelerin anayasalarınun getirdikleri düzenlemeleri görelim.

A.B.D2.- Amerika Birleşik Devletleri Federal Anayasasının ${ }^{3}$ 2'nci maddesinin 2'nci bölümünün 2'nci fikrası, uluslararası andlaşmalan akdetme yetkisini Başkana vermektedir.

Almanya ${ }^{4}$.- 1949 Alman Anayasas1 ${ }^{5}$, Federasyon adına yabana devletler ile andlaşma akdetme yetkisini Cumhurbaşkanuna vermektedir (m.59/1). Cumhurbaşkanunın uluslararası andlaşma akdetme yetkisi karşı-imza kuralına tábidir (m.58). Bu şu anlama gelir ki, Almanya'da uluslararası andlaşma yapma alaninda sorumluluk, esasen Hükamet tarafından üstlenilir (AUTEXIER, 1997:156).

Belçika.- 1994 Belçika Anayasası6, "Bölge ve Topluluk Hükâmetleri (Gouvernements de communauté et de région)"ne kendi Konseylerinin yetki alanına giren konularda uluslararası andlaşma akdetme yetkisi vermektedir (m.167/3). $\mathrm{Bu}$ andlaşmaların dışında kalan andlaşmalan akdetme yetkisi Krala aittir (m.167/2). Kralın bu yetkisi tüm diğer yetkileri gibi karşı-imza kuralına tábidir (m.106).

Danimarka.- 1953 Danimarka Anayasası 7 , Krala, Krallık adına uluslararası andlaşma akdetme yetkisini vermiştir (bölüm 19/1). Ancak Kralın tüm diğer yetkileri gibi bu yetkisi de karşı-imza kuralına tâbidir (bölüm 14).

Finlandiya.- 1999 Finlandiya Anayasasına ${ }^{8}$ göre Finlandiya'nın dış politikası Hükamet ile işbirliği halinde Cumhurbaşkanı tarafından yönetilir (m.93). Dolayısıyla Finlandiya'da uluslararası andlaşma akdetme yetkisinin Hükámet ile işbirliği halinde Cumhurbaşkanına ait olduğunu söyleyebiliriz (m.93).

2 Amerika Birleşik Devletlerinde uluslararası akdetme yetkisi konusunda bkz.: (TRIBE, 2000: 643-656; NOWAK / ROTUNDA / YOUNG, 1978: 183-203; BARTHOLOMEW, 1970: 97; MASON / BEANEY, 1964: 60-61).

317 Eylül 1787 tarihli Amerika Birleşik Devletleri Federal Anayasasının Ingilizce ash için bkz.: http://www.constitution. org/ constit_.htm (1.2.2001).

4 Almanya'da uluslararası andlaşma akdetme yetkisi hakkında bkz. (AUTEXIER, 1997: 156; JACKSON / TUSHNET, 1999: 716-718).

523 Mayıs 1949 tarihli Alman Anayasasının Ingilizce çeviri metni için bkz.: http://www.uni-wuerzburg.de/ law/gm00000_html (1.2.2001).

617 Subat 1994 tarihli Belçika Anayasasının Fransızca aslı için bkz.: http://www.senate.be/ senbeldocs/ constitution/ const_fr.html (1.2.2001); lngilizce çeviri metni için bkz.: http://www.uni-wuerzburg.de/ law/ be00000_.html. (1.2.2001).

75 Haziran 1953 tarihli Danimarka Anayasasının Ingilizce çeviri metni için bkz.: http://www.uni-wuerzburg.de/ law/da00000_html (1.2.2001).

811 Haziran 1999 tarihli Finlandiya Anayasasının Ingilizce çeviri metni için bkz: http://www.om.fi/ constitution/ 3340.htm (1.2.2001). 
Fransa ${ }^{9}$.- 1958 Fransız Anayasasına ${ }^{10}$ göre, "Cumhurbaşkan andlaşmalan müzakere eder ve onaylar" (m.52). Dolayısıyla 1958 Fransız Anayasasının uluslararası andlaşmalan "müzakere (négociation)" etme yetkisini Cumhurbaşkanuna verdiğini söyleyebiliriz (m.52). Cumhurbaşkanunun bu yetkisi karşı-imza kuralına tábidir (m.19). Ancak 1958 Fransız Anayasasının 52'nci maddesinin ikinci fıkrası, "onaya tábi olmayan uluslararası andlaşmaların akdedilmesine ilişkin bütün müzakerelerden Cumhurbaşkanı haberdar edilir" dediğine göre, Anayasanun iki tür uluslararası andlaşma öngördüğünü söyleyebiliriz. Birinci tür andlaşmalar onaya tåbidir ve bu andlaşmalar Cumhurbaşkan tarafından müzakere edilir. Ikinci tür andlaşmalar ise onaya tabi değildir. 52'nci maddenin ikinci fıkrasında öngörülmüş olan bu ikinci tür andlaşmalara "basit sekilde andlaşmalar (accords en forme simplifiée)" denmektedir (ZOLLER, 1999: 478; CHAGNOLLAUD, 1999: 301; GICQUEL, 1999: 485; FAVOREU et al., 1998: 187). Işte bu ikinci tür andlaşmalar bakımından müzakere ve akdetme yetkisi Cumhurbaşkanuna değil, Hükúmete, yani Başbakan veya Dışişleri Bakanına aittir (ZOLLER, 1999: 477). Bu andlaşmaların onaylanmasına gerek yoktur. Bunlar imzalanmalanyla birlikte yürürlüğe girer (PACTET, 1994: 502).

İngiltere.- Ingiltere'de bir anayasal konvansiyona göre, uluslararası andlaşma akdetme yetkisi Taca ait bir yetkidir. Andlaşma akdedilmesi için görüşmeler Taan görevlileri tarafından yürütülür. Kraliçenin bu yetkisi tüm diğer yetkileri gibi karşı-imza kuralına tábidir (HOOD PHILLIPS / JACKSON, 1987: 285-287; DE SMITH / BRAZIER, 1989: 139-150).

İrlanda.- 1937 Irlanda Anayasasına ${ }^{11}$ göre dış ilişkiler alanında yürütme yetkisi Hükamet tarafından kullanlır (m.29/4-1). Yani Irlanda'da uluslararası andlaşma akdetme yetkisi doğrudan Hükâmete aittir.

İsveç.- 1975 Isvę Anayasası ${ }^{12}$, diğer devletler ile veya uluslararası örgütler ile andlaşma akdetme yetkisini Krala değil, Hükamete vermektedir (bölüm 10, m.1). Hükûmet Parlåmentonun uygun bulması gerekli olmayan andlaşmalan akdetmek için bir idarî makamı görevlendirebilir (bölüm 10, m.3).

9 Fransa'da uluslararası andlasma akdetme yetkisi konusunda bkz. : (FAVOREU et al., 1998: 185-190; ZOLLER, 1999: 477-479; CHAGNOLLAUD, 1999: 301-302; GICQUEL, 1999: 484-486; LAVROFF, 1995: 193-198; PACTET, 1994: 501-509).

104 Ekim 1958 tarihli Fransız Anayasasının Fransızca aslı için bkz.: http://www.legifrance. gouv.fr/html/frame_ constitution.htm (1.2.2001); Ingilizce çeviri metni için bkz.: http://www. assemblee-nationale.fr/ 8/8ab.htm (1.2.2001).

111 Temmuz 1937 tarihli Irlanda Anayasasının Ingilizce aslı için bkz:: http://www.math.tcd.ie/pub/ Constitution.html (1.2.2001).

121 Ocak 1975 tarihli Isveç Anayasasınun Ingilizce çeviri metni için bkz.b: http://www.uni-wuerzburg.de/ law/sw00000_html (1.2.2001). 
Ísviçre.- 1999 Isviçre Anayasasına ${ }^{13}$ göre dış ilişkileri yürütme, Isviçre'yi dişarda temsil etme (m.184/1) ve andlaşma imzalamak yetkisi Federal Hükumete aittir (m.184/2).

Izlanda.- 1944 tzlanda Anayasasına14 göre, diğer devletlerle andlaşma akdetme yetkisi Cumhurbaşkanına aittir (m.21). tzlanda da Cumhurbaşkanının bu yetkisi karşı-imza kuralına tåbidir (m.19).

Japonya.- 1946 Japon Anayasas ${ }^{15}$ ise dış ilişkileri yürütmek (m.73/2) ve uluslararası andlaşma akdetmek yetkisini, Krala değil, doğrudan Hükûmete vermiștir (m.73/3).

Lüksemburg.- 1868 Lüksemburg Anayasasına ${ }^{16}$ göre uluslararası andlaşma akdetme yetkisi Büyük Düke aittir (m.37). Büyük Dükün bu yetkisi karş1-imza kuralına tábidir (m.45).

Norveç.- 1814 Norveç Anayasası 17 , uluslararası andlaşmalan akdetme ve feshetme yetkisini Krala vermiştir (m.26). Kralın bu yetkisi tüm diğer yetkileri gibi karşı-imza kuralına tåbidir (m.31).

Portekiz.- 1976 Portekiz Anayasası ${ }^{18}$, uluslararası andlaşmaları görüşme ve akdetme yetkisini Cumhurbaşkanuna değil, doğrudan Hükamete vermektedir (m.200/1-b).

Yunanistan.- 1975 Yunan Anayasasına ${ }^{19}$ göre, devleti uluslararası planda temsil etme yetkisi Cumhurbaşkanuna aittir (m.36/1). Keza, barış, ittifak, ekonomik işbirliği ve uluslararası örgütlere katılma konusunda uluslararası andlaşmalar akdetme yetkisi Cumhurbaşkanuna aittir (m.36/1). Cumhurbaşkanunun bu yetkisi karşı-imza kuralına tábidir (m.35).

1929 Avusturya Anayasası, 1983 Hollanda Anayasası, 1978 Ispanyol Anayasası, tsrail Temel Kanunlan ve 1982 Türk Anayasası uluslararası

1314 Nisan 1999 tarihli Isviçre Anayasasının Fransızca aslı için blkz.: http://www.admin.ch/ $\mathrm{ch} / \mathrm{f} / \mathrm{ss} / 101 /$ index.html (1.2.2001); Ingilizce çeviri metri için bkz.: http://www.uni-wuerzburg.de/ law/ sz00000_html (1.2.2001).

1417 Haziran 1944 tarihli Izlanda Anayasasının Ingilizce çeviri metni için bkz:: http://www. richmond.edu/ - jpjones/confinder/lceland2.htm (1.2.2001).

153 Kasım 1946 tarihli Japon Anayasasının Ingilizce çeviri metni için bkz.: http://www.uni-wuerzburg.de/ law/ja00000_html (1.2.2001).

1617 Ekim 1868 tarihli Lüksemburg Anayasasının Fransızca ash için bkz: http://www.etat.lu/SCL/ CNST0999.PDF (10.3.2001); Ingilizce çeviri metni için bkz.: http://www.uni-wuerzburg.de/law/lu__indx.html (1.2.2001).

1717 Mayıs 1814 tarihli Norvẹ Anayasasının Ingilizce çeviri metni için bkz.: http://odin.dep.no/ odin/ engelsk/ norway/ system/032005-990424/ index-dok000-b-n-a.html (1.2.2001).

182 Nisan 1976 tarihli Portekiz Anayasasınun Ingilizce çevirisi için bkz.: http://www. parlamento.pt/ constit/ crp_ing.html (1.2.2001).

199 Haziran 1975 tarihli Yunan Anayasasınen Ingilizce çeviri metni için bkz: http://www.uni-wuerzburg.de/law/ gr0000_html (1.2.2001). 
andlaşma akdetme yetkisine ilişkin bir hüküm içermemektedir. Bu ülkelerde de uluslararası andlaşma akdetme yetkisinin yasama organlanna değil, yürütme organlarnna ait olduğunu söyleyebiliriz. Zira, 1969 Viyana Andlaşmalar Hukuku Sözleşmesine göre (m.7), dışişleri bakanları, hükûmet başkanlan ve devlet başkanları uluslararası andlaşmalan akdetme yetkisine genel olarak sahiptirler.

\section{B. KARŞILAŞTIRMA}

Yukarıda incelediğimiz ülkelerin uluslararası andlaşmalan akdetme yetkisinin verildiği organ bakımından anayasal düzenlemeleri karşılaştırıldığında şu sonuçlar ortaya çlkmaktadır:

1. Akdetme Yetkisi Yürütme Organuna Verilmiştir.- Incelediğimiz ülkelerin hepsinde uluslararası andlaşmalan akdetme yetkisi yürütme organına aittir. Bu kuralın bir istisnası yoktur. Monist yürütme organina sahip Amerika Birleşik Devletlerinde problem yoktur. Bu ülkede uluslararası anciiaşma akdetme yetkisi Başkana aittir (m.2,b.2,f.2). Ancak, düalist yürütme organına sahip ülkelerde, yürütme organunun kendi içinde uluslararası andlaşma akdetme yetkisinin hangi organa verildiğinin aynca saptanması gerekir. Yürütme organ düalist yapıda olan ülkelerin çoğunluğunda akdetme yetkisi, devlet başkanına, azınlığında ise hükâmete verilmiştir.

2. Akdetme Yetkisini Devlet Başkanına Verenler.- Uluslararası andlaşma akdetme yetkisi Almanya'da Cumhurbaşkanuna (m.59), Belçika'da Krala (m.167/2), Danimarka'da Krala (bölüm 19), Finlandiya'da Cumhurbaşkanına (m.93), Fransa'da ise onaya tâbi andlaşmalar bakımından Cumhurbaşkanuna (m.52), Ingiltere'de Taca; Izlanda'da Cumhurbaşkanına (m.21), Lüksemburg'ta Büyük Düke (m.38), Norveçte Krala (m.26), Yunanistan'da Cumhurbaşkanına (m.36) verilmiştir.

3. Hükûmete Verenler.- Incelediğimiz ülkeler arasında uluslararası andlaşma akdetme yetkisi, trlanda'da (m.29/4-1), Isveç'te (Bölüm 10, m.1), Isviçre'de (m.184), Japonya'da (m.73/3) ve Portekiz'de (m.200/1-b) Hükámete verilmiştir. Fransa'da ise, onaya tåbi olan andlaşmalan akdetme yetkisi Cumhurbaşkanuna verilmekle birlikte, onaya tâbi olmayan ve kendilerine "basit şekildeki andlaşmalar (accords en forme simplifiée)" denilen andlaşmaları akdetme yetkisi Hükûmete verilmiştir (m.52/2).

4. Karşı-İmza Kuralı.- Parlâmenter hükamet sistemine sahip ülkelerde, uluslararası andlaşma akdetme yetkisi, devlet başkanuna verilmiş ise, devlet başkanının bu yetkisi karşı-imza kuralına tâbi tutulmuştur: 1949 Alman Anayasası (m.58), 1994 Belçika Anayasası (m.106), 1953 Danimarka Anayasası (bölüm 14), 1999 Finlandiya Anayasası (m.93), 1958 Fransız Anayasası (m.19), Ingiltere (konvansiyon), 1944 Izlanda Anayasası (m.19), 1868 Lüksemburg 
Anayasası (m.45), 1814 Norveç Anayasası (m.31), 1975 Yunan Anayasası (m.35). $\mathrm{Bu}$ ülkelerde devlet başkanları uluslararası andlaşma akdetme yetkisini ancak başbakan ve dışişleri bakanının karşı-imzasın alarak kullanabilir. Bu durum parlâmenter demokrasinin temel ilkeleriyle uyuşum içindedir. Zira, parlâmenter demokrasilerde dıs politika alanunda sorumluluk, devlet başkanlanna değil, hükametlere aittir. Sorumluluk hükumetlere ait olduğuna göre, uluslararası andlaşma akdetme yetkisini devlet başkanlarının tek başına kullanamaması gerekir.

\section{ONAY YETKISI}

Yürütme organı tarafından akdedilen, yani görüşülüp metni kaleme alınan ve altı imzalanan bir andlaşma bağlayı güç kazanı derhal yürürlüğc girmez. Bunun için, akdedilmiş olan andlaşmanun bir de "onaylanması (ratification)" gerekir. Anlaşmayı onaylamaya yetkili olan makam, her ülkenin kendi iç hukuku tarafından tespit edilir. Bu konuda ilk önce yirmi iki ülkenin anayasal düzenlemelerini görelim.

\section{A. AMAYASAL düZENLEMELER}

Amerika Birleşik Devletleri ${ }^{20}$.- Amerika Birleşik Devletleri Anayasası ${ }^{21}$ andlaşma yapma yetkisini Başkana, onaylama yetkisini ise Senatoya vermiştir. Senato onaylama yetkisini üye tamsayısının üçte iki çoğunluğuyla alacağı bir kararla kullanır (m.2,b.2,f.2). Amerika Birleşik Devletlerinde Başkanın uluslararası andlaşma yapma yetkisi, Senatonun onayına tâbi olmakla birlikte, Başkanın Senatonun onayını almadan, bazı durumlarda, "executive agreements" denen andlaşmalar yapma yetkisinin olduğu kabul edilmektedir (TRIBE, 2000: 648-656; NOWAK / ROTUNDA / YOUNG, 1978: 183-203; BARTHOLOMEW, 1970: 95; CRONIN, 1980: 193-195). Ancak Başkanın böyle andlaşmalar yapabilmesi için, ya Anayasanun kendisine açıç̧a verdiği bir yetkiye dayanması ${ }^{22}$, yahut bu andlaşmanun daha önceden Senato tarafindan onaylanan bir başka andlaşma tarafından öngörülüyor olması, veyahut Başkanın daha önceden Kongrenin iznini alması gerekmektedir (NOWAK / ROTUNDA / YOUNG, 1978: 188). Executive agreements denen andlaşmaların iç hukuk

20 Amerika Birleşik Devletlerinde uluslararası andlaşmalan onaylama yetkisi konusunda bkz:: (TRIBE, 2000: 643-656; NOWAK/ ROTUND /YOUNG; 1978: BARTIIOLOMEW, 1970: 97; MASON/BEANEY, 1964: 60-61; CRONIN, 1980: 193-195; JACKSON/ TUSI INET, 1999: 714-716).

2117 Eylül 1787 tarihli Amerika Birleşik Devletleri Federal Anayasasının Ingilizce ash için bkz.: http://www.constitution. org/ constit_htm (1.2.2001).

22 Ömeğin Başkanın silahlı kuvvetlerin baş komutanlığını yapmak yetkisine dayanarak executioe agreement' lar yapabileceği kabul edilmektedir. 
bakımından bağlayıc olmadığı baştan kabul edilmişse de (Altman and Company v. United States, 224 U.S. 583 [1912]), Yüksek Mahkeme United States v. Belmont (301 U.S. 324 [1937]) kararında ${ }^{23}$ executive agreement'ların da diğer andlaşmalar (treaties) gibi bağlayı olduğunu kabul etmiştir (NOWAK / ROTUNDA / YOUNG, 1978: 189). Yüksck Mahkeme, United States v. Pink (315 U.S. 203 [1942]) karanında da uluslararası andlaşmalar (treaties) ile executive agreement'ların aynı hukukî değerde bulunduğuna karar vermiştir (BARTHOLOMEW, 1970: 97; MASON / BEANEY, 1964: 61).

Almanya.- 1949 Alman Anayasasına ${ }^{24}$ göre (m.59/2), Federasyonun dı̧ ilişkilerini düzenleyen veya federal yasama yetkisi alanuna giren andlaşmaların, Cumhurbaşkan tarafindan onaylanabilmesi için, federal yasama alanında yetkili organlar, yani parlâmento tarafından, bir federal kanun şeklinde uygun bulunmalan gerekir (AUTEXIER, 1997: 157).

Avusturya.- 1929 Avusturya Anayasasına ${ }^{25}$ göre "siyasal andlaşmalar" ve "mevcut kanunların içeriğinde değişiklik yapan diğer andlaşmalar", ancak Nationalrat'in uygun bulmasiyla akdedilebilirler (m.50/1). Uygun bulma esnasında Nationalrat, söz konusu andlaşmanın kanunla yürürlüğe konulup konulmayacağına da karar verir (m.50/2). Anayasanın bir hükmünü değiştiren veya Anayasada değişiklik yapan uluslararası andlaşmalar, Nationalrat'ın üye tamsayısınun en az salt çoğunluğunun bulunduğu toplantida üçte iki oy çoğunluğuyla uygun bulunabilir (m.50/3 gereğince m.44/1). 50'nci maddede belirtilen andlaşmalar, Nationalrat tarafından onaylandıktan sonra "Federal Sansölye (Bundeskanzler)" tarafından "Federal Kanun Gazetesi (Bundesgesetzblatt)"nde yayınlanir (m.49/1). Ancak "Federal Başkan (Bundespräsident)", 50'nci madde kapsamına giren andlaşmalar dışıındaki andlaşmaları, Nationalrat'ın onayı olmaksızın "kararname (Verordnung)" ile yürürlüğe koyabilir (m.65/1). Cumhurbaşkanının bu yetkisi karşı-imza kuralına tábidir (m.67).

Belçika.- 1994 Belçika Anayasası ${ }^{26}, \mathrm{Kral}$ tarafından akdedilen andlaşmaları onaylama yetkisini Meclislere vermektedir (m.167/2). Anayasada Meclislere sunulmadan onaylanabilecek bir andlaşma belirtilmediği için bu kural mutlak niteliktedir. Belçika'da bütün andlaşmalar, Meclislerin onayına sunulur.

23 Keza aynı yönde bkz.: United States o. Curtiss-Wright Corp, 315 U.S. 230 (1936). Karann metni için bkz..: ( MASON /e BEANEY, 1964: 95-98).

2423 Mayıs 1949 tarihli Alman Anayasasının Ingilizce çevirisi için bkz.: http://www.uni-wuerzburg.de/ law/gm00000_html (1.2.2001).

251929 A vusturya Anayasasının (Bundes-Verfassungsgesetz in der Fassung oon 1929) Ingilizce çeviri metni için bkz.: http://www.uni-wuerzburg.de/ law/as 00000 _html (1.2.2001).

2617 Şubat 1994 tarihli Belçika Anayasasının Fransızca aslı için bkz.: http://www.senate.be/ senbeldocs/ constitution/ const_fr.html (1.2.2001); Ingilizce çevirisi için bkz.: http://www.uni-wuerzburg.de/law/ be00000_html. (1.2.2001). 
Danimarka.- 1953 Danimarka Anayasasına ${ }^{27}$ göre Kral, Kraliyet ülkesini genişleten veya daraltan uluslararası andlaşmalan ve keza büyük bir öneme sahip diğer andlaşmaları, Parlåmentonun rızasını almaksızın onaylayıp yürürlüğe koyamaz (bölüm 19/1). Kralın tüm diğer yetkileri gibi onay yetkisi de karş1-imza kuralına tâbidir (bölüm 14).

Finlandiya.- 1999 Finlandiya Anayasasına 28 göre Finlandiya'nın dış politikası Hükûmet ile işbirliği halinde Cumhurbaşkan tarafından yönetilir (m.93). Dolayısıyla Finlandiya'da uluslararası andlaşmalan onaylama yetkisinin hükomet ile işbirliği halinde Cumhurbaşkanuna ait olduğunu söyleyebiliriz (m.93). Bununla birlikte teşrî́ nitelikte hüküm içeren andlaşmalar veya diğer bir şekilde önem arz eden andlaşmalarnn Parlâmento tarafından uygun bulunması gerekir (bölüm 94/1). Parlâmentoda uygun bulma kararı için gereken karar yetersayısı kullanlan oyların salt çoğunluğudur (bölüm 94/2). Bununla birlikte Anayasaya ilişkin olan veya ulusal sinurlarda değişiklik yapan andlaşmaların onaylanabilmesi veya feshi için karar yetersayısı kullanılan oyların üçte ikisidir (bölüm 94/2, 95/2). Bir uluslararası andlaşma Anayasanun demokratik temellerine dokunamaz (m.94/3). Teşrî nitelikteki uluslararası andlaşmalar, kanunla yürürlüğe konulabilir (bölüm 95/1). Diğer uluslararası andlaşmalar ise, Parlâmento tarafından uygun bulunmalanna ihtiyaç olmaksızın doğrudan doğruya Cumhurbaşkanı tarafından onaylanırlar ve Cumhurbaşkan tarafından çkanlacak bir kararname ile yürürlüğe konulurlar (bölüm 95/1). Bu kararnameler karşı-imza kuralına tâbidir (bölüm 58).

Fransa $^{29}$.- 1958 Fransız Anayasası ${ }^{30}$, uluslararası andlaşmaları onaylama yetkisini Cumhurbaşkanina vermektedir (m.52). Onaylama bir "onay kararnamesi (décret de ratification)"nin Resmî Gazetede yayınlanması suretiyle gerçekleştirilir (GICQUEL, 1999: 485; FAVOREU et al., 1998: 187). 1958 Fransız Anayasasına göre Cumhurbaşkanınun uluslararası andlaşmaları onaylama yetkisi karşı-imza kuralına tâbidir (m.19). Ancak Cumhurbaşkanının, Anayasanın 53 'üncü maddesinin birinci fıkrasında sayılan yedi grup andlaşmayı onaylayabilmesi için, Parlâmentonun iznini alması gerekir (m.53/1). Parlâmento bu izni bir kanunla verir (m.53/1). Bu yedi grup andlaşma şunlardır: (a) Barıs andlaşmalan, (b) ticaret andlaşmalan, (c) uluslararası organizasyona ilişkin

275 Haziran 1953 tarihli Danimarka Anayasasının Ingilizce çeviri metri için bkz..: http://www.uni-wuerzburg.de/ law/da00000_html (1.2.2001).

2811 Haziran 1999 tarihli Finlandiya Anayasasının Ingilizce çeviri metni için bkz.: http://www.om.fi/ constitution/3340.htm (1.2.2001).

29 Fransa'da uluslararası andlaşmalan onaylama yetkisi konusunda bkz.: (FAVOREU et al., 1998: 190-192; ZOLLER, 1999: 477-479; CHAGNOLLAUD, 1999: 301-302; GICQUEL, 1999: 484-486; LAVROFF, 1995: 193-198; PACTET, 1994: 501-509).

304 Ekim 1958 tarihli Fransvz Anayasasının Fransızca ashı için bkz.: http://www.legifrance. gouv.fr/html/frame_ constitution.htm (1.2.2001); Ingilizce çeviri metni için bkz.: http://www.assemblee-nationale.fr/8/8ab.htm (1.2.2001). 
andlaşmalar, (d) devletin maliyesine yük getiren andlaşmalar, (e) teşrif nitelikteki hükümlerde değişiklik yapan andlaşmalar, (f) kişi hallerine ilişkin andlaşmalar, $(\mathrm{g})$ toprak değişimi, terki ve ilavesi öngören andlaşmalar (m.53/1). Eğer Anayasa Konseyi bir uluslararası andlaşmanun Anayasaya aykun bir hüküm içerdiğine karar verirse, böyle bir andlaşmanın onaylanmasına, ancak, Anayasa değişikliğinden sonra izin verilebilir (m.54). Anayasa Konseyine bu amaçla, Cumhurbaşkanu, Başbakan, Meclis Başkanları, 60 milletvekili veya 60 senatör başvurabilir (m.54). Cumhurbaşkan bu andlaşmalar dışında kalan uluslararası andlaşmalan, Parlâmentonun iznini almadan onaylayabilir. Cumhurbaşkanunun bu andlaşmalan onaylama yetkisi de karşı-imza kuralına tåbidir (m.19).

Hollanda.- 1983 Hollanda Anayasasına ${ }^{31}$ göre, uluslararası andlaşmalar, Parlåmentonun uygun bulması olmaksızın Krallığı bağlayamazlar (m.91/1). Parlâmentonun işlemleri Kral tarafından onaylanır (m.87/1). Ancak Anayasa bütün andlaşmalar için Parlâmentonun uygun bulması şartın öngörmemektedir. Zira Anayasaya göre, Parlâmentonun uygun bulmasının gerekli olmadığ andlaşmalar kanunla belirlenecektir (m.91/1). O halde kanunla belirlenen bu andlaşmalan yürütme organı (Kral ve Hükamet), Parlâmentonun uygun bulunması olmaksızın onaylayabileceklerdir. Anayasaya aykır olan andlaşmalann uygun bulunabilmesi için Parlâmentonun her iki Meclisi tarafından üçte iki oy çoğunluğuyla kabul edilmesi gerekir (m.91/3). Keza, yasama, yürütme ve yargı yetkilerinin uluslararası kurumlara devrine ilişkin olan andlaşmaların Parlâmento tarafından uygun bulunabilmesi için de Parlâmentonun her iki Meclisi tarafından üçte iki oy çoğunluğu ile kabul edilmesi gerekir ( $m .92$ gereğince m.91/3).

Ingiltere.- Ingiltere'de bir anayasal konvansiyona göre, uluslararası andlaşmaları onaylama yetkisi Taca aittir (HOOD PHILLIPS / JACKSON, 1987: 285; DE SMITH / BRAZIER, 1989: 140). Andlaşmalar bir "hükâmet tasarrufu (act of state)" olarak kabul edilirler ve bu nedenle, kural olarak, onaylanmadan önce Parlâmento tarafından uygun bulunmalan gerekli değildir (HOOD PHILLIPS / JACKSON, 1987: 285). Ancak 1924 'ten beri tekrarlanan ve artik bir anayasal konvansiyon olarak görülen bir uygulamaya göre, andlaşmalar, Kraliçe tarafından onaylanmadan 21 gün önce Parlâmentonun her iki Meclisine sunulmaktadir (HOOD PHILLIPS / JACKSON, 1987: 285; DE SMITH / BRAZIER, 1989: 140). Buna "Ponsonby Kuralı" denmektedir (HOOD PHILLIPS / JACKSON, 1987: 285; MIRKINE-GUETZEVITCH，1933: 133). Parlâmentoya sunulan uluslararası andlaşmalar üzerinde iktidar veya muhalefet partileri, Parlâmentoda bir tartı̧ma başlatabilirler (HOOD PHILLIPS /JACKSON, 1987:

3117 Subat 1983 tarihli Hollanda Anayasasının Ingilizce çeviri metni için bkz: http://www.uni-wuerzburg.de/law/nl00000_.html (1.2.2001). 
285). Bununla birlikte Ingiltere'de şu andlaşmaların "Parlâmento tarafından teyit (confirmation by Parliament)"32 edilmesi gerektiği kabul edilmektedir: (a) Parlâmento tarafından teyid edilmesini öngören andlaşmalar 33 ; (b) Ingiliz hukukunda değişiklik getiren andlaşmalar (HOOD PHILLIPS / JACKSON, 1987: 286); (c) vergilendirme ve kamu harcamalarına ilişkin andlaşmalar (A.C. 326, 347 [1937]; HOOD PHILLIPS / JACKSON, 1987: 286); (d) özel haklara dokunan andlaşmalar (The Parliament Belge [1879], 4. P.D., 129, 154; HOOD PHILLIPS / JACKSON, 1987: 286). Bu dört grup andlaşmanun dışında "toprak terki" ve "deniz sınırlarının belirlenmesine" ilişkin uluslararası andlaşmaların da Parlâmento tarafından teyid edilmesi gercktiği ileri sürülmektedir (HOOD PHILLIPS / JACKSON, 1987: 287).

İrlanda.- 1937 Irlanda Anayasasına ${ }^{34}$ göre dış ilişkiler alanında yürütme yetkisi Hükûmet tarafindan kullanılır (m.29/4-1). Dolayısıyla Irlanda'da uluslararası andlaşmaları akdetme ve onaylama yetkisi Hükúmete aittir. 1937 Irlanda Anayasasına göre, devletin taraf olduğu bütün andlaşmalar, Dail Eireann'ın önüne getirilmelidir (m.29/5-1). Keza kamu maliyesine yük getiren andlaşmalar, Dail Eireann tarafından uygun bulunmalıdır (m.29/5-1). Bununla birlikte teknik ve idarî nitelikteki andlaşmaların Parlâmentoya sunulmalan gerekli değildir (m.29/5-3).

İspanya.- 1978 Ispanyol Anayasasi ${ }^{35}$, uluslararası andlaşmalan onaylama yetkisini Krala vermektedir (m.63/2). Kralın onaylama yetkisi karşı-imza kuralına tâbidir (m.64). Ancak Kralın şu andlaşmaları onaylayabilmesi için Cortes Generales'in iznini alması gerekir: (a) Siyasal nitelikteki andlaşmalar, (b) askerî niteliktcki andlaşmalar ve sözleşmeler, (c) devlet ülkesinin bütünlüğüne veya birinci başlikta düzenlenen temel hak ve ödevlere dokunan andlaşmalar, (d) devlet hazinesine borç yükleyen andlaşmalar, (e) bir kanunda değişiklik yapan veya bir kanunu ilga eden andlaşmalar veya uygulanması için tę̧rî̂ tedbirler gerektiren andlaşmalar (m.94/1). 1978 Ispanyol Anayasasına göre, Anayasaya aykırı hükümler içeren bir uluslararası andlaşmanın onaylanabilmesi için öncelikle Anayasada değişiklik yapılması gerekir (m.95/2).

32 Uygulamada Parlâmentonun kabulüne "onay (ratification)" deniyorsa da, bu onay değildir; zira Parlâmento tarafindan kabul edilmiş andlaşmalar daha sonra Taç tarafindan onaylanacaktır. O halde "onay (ratification)" terimi, Tacın andlaşma üzerindeki "nihaî mevsukiyet (final authentification)" işlemi için kullandmalıdır (IIOOD PHILLIPS / JACKSON, 1987: 285).

33 Yani bir andlaşmanın kendisi onay için Parlâmento tarafından teyid edilmesini öngörüyorsa, bu andlaşma Parlâmento tarafından teyid edilmeden Taç tarafından onayla nup yürürlüğe sokulamaz (l HOOD PHILLIIS / JACKSON, 1987: 285).

341 Temmuz 1937 tarihli Irlanda Anayasasinin Ingilizce aslı için bkz:: http://www.math.ted.ie/pub/ Constitution.html (1.2.2001).

3527 Aralık 1978 tarihli ispanyol Anayasasının Ingilizce seviri metni için bkz.: http://www.uni-wuerzburg.de / law/sp00000 ... html (1.2.2001). 
Bir andlaşmanın Anayasaya aykın olup olmadığı konusunda Hükâmet veya meclislerden her biri Anayasa Mahkemesine başvurabilir (m.95/2). Anayasanın 94'üncü mađdesinin beşinci fikrasında saylan bes grup andlaşma dışında kalan andlaşmalar, Parlâmentonun izni olmaksızın, Kral tarafından doğrudan doğruya onaylanabilir (m.94/2). Kralın doğrudan onaylama yetkisi karşı-imza kuralına tâbidir (m.64). Ancak, bunlann akdedilmesinden Milletvekilleri Kongresi ve Senato derhal haberdar edilir (m.94/2).

Israil.- 16 Haziran 1964 tarihli Devlet Başkan Hakkında Israil Temel Kanununa ${ }^{36}$ göre, Knesset tarafından onaylanmış uluslararası andlaşmalan imzalama yetkisi Cumhurbaşkanına aittir (bölüm 11/5).

İsveç.- 1975 Isveç Anayasas ${ }^{37}$ uluslararası andlaşma yapma yetkisini Hükamete vermektedir (bölüm 10, m.1). Ancak bir kanunda değişiklik yapan veya kanunu ilga eden veya yeni bir kanun çlkarılmasını öngören uluslararası andlaşmalar, Parlâmento tarafından uygun bulunmadıkça Krallıkta bağlayıcı güç kazanamazlar (bölüm 10, m.2/1). Keza Hükûmet, büyük bir öneme sahip andlaşmaları da Parlâmentonun uygun bulmasın elde etmeden yapamaz (bölüm 10, m.2/3). Bununla birlikte, Hükûmet, Krallığın menfaati gerektiriyorsa, Parlâmentonun uygun bulması olmadan da uluslararası andlaşma yapabilir. Bu durumda Hükúmet andlaşmayı akdetmeden önce, "Dışişleri Danışma Konscyi (Foreign Affairs Advisory Council)"nin görüşünü almalıdır (bölüm 10, m.2/3).

İsviçre.- 1999 Isviçre Anayasasına 38 göre uluslararası andlaşmalan imzalamak ve onaylamak yetkisi, Federal Hükamete aittir (m.184/2). Ancak onaylanmaları için andlaşmaların Parlâmento tarafından uygun bulunmaları gerekir (m.184).

İtalya.- 1947 Italyan Anayasası ${ }^{39}$ uluslararası andlaşmaları onaylama yetkisini Cumhurbaşkanına vermiştir (m.87/8). Cumhurbaşkanının bu yetkisi karşı-imza kuralına tâbidir (m.89). Ancak Cumhurbaşkanı Anayasanın 80'inci maddesinde sayılan beş grup andlaşmayı ancak Parlâmentonun iznini aldıktan sonra onaylayabilir. Bu bes grup andlaşma şunlardır: (a) Siyasal nitelikteki andlaşmalar, (b) tahkim veya adlî düzenlemeler öngören andlaşmalar, (c) toprak

3616 Haziran 1964 tarihli Devlet Başkanı Hakkında Israil Temel Kanununun (Basic Law: The President of the State) Ingilizce çeviri metni için bkz.: http://www.uni-wuerzburg.de/ law/is_indx.html (1.2.2001).

371 Ocak 1975 tarihli lsvę Anayasasının Ingilizce şeviri metni için bkz.b: http://www.uni-wuerzburg.de/law/sw00000_html (1.2.2001).

3814 Nisan 1999 tarihli Isviçre Anayasasının Fransızca aslı için bkz.: http://www.admin.ch/ $\mathrm{ch} / \mathrm{f} / \mathrm{rs} / 101 /$ index.html (1.2.2001); Ingilizce çeviri metni için bkz.: http://www.uni-wuerzburg.de/ law/ sz00000_html (1.2.2001).

3927 Aralık 1947 tarihli Italyan Anayasasının Italyanca aslı için bkz.: http://www.palazzochigi.it/ sez_costituzione.html (1.2.2001); Ingilizce çeviri metni için bkz:: http://www.uni-wucrzburg.de/ law/it00000_html (1.2.2001). 
değişikliği içeren andlaşmalar, (d) maliyeye yük getiren andlaşmalar, (e) kanunlarda değişiklik öngören andlaşmalar (m.80).

İzlanda.- 1944 Izlanda Anayasası ${ }^{40}$, diğer devletlerle andlaşma yapma ve onaylama yetkisini Cumhurbaşkanuna vermiştir (m.21). Ancak Cumhurbaşkan, Althingi'nin onayı olmaksızın, ülke veya karasulan üzerinde vazgeçme veya irtifak tanumasına ilişkin anlaşmalan ve keza devlet sisteminde değişiklik öngören andlaşmaları yapamaz (m.21). tzlanda da Cumhurbaşkanının onay yetkisi karşı-imza kuralına tåbidir (m.19).

Japonya.- 1946 Japon Anayasasına ${ }^{41}$ göre Hükamet tarafindan yaplan uluslararası andlaşmalar, Dietin onayın gerektirir (m.73/3). Bu onay önceden veya duruma göre sonradan elde edilebilir (m.73/3). Hükûmet tarafindan akdedilmiş, Diet tarafından onaylanmıs uluslararası andlaşmalar, Bakanlar Kurulunun görüşü ve onayıyla, Imparator tarafından ısdar edilirler (m.7/1).

Lüksemburg.- 1868 Lüksemburg Anayasasına ${ }^{42}$ göre Büyük Dük tarafından akdedilmiş andlaşmaların yürürlüğe girebilmesi için bir kanunla onaylanmaları gerekir (m.38/1). Lüksemburg'ta da istisnasız bütün andlaşmalar Parlåmentonun onayına sunulur. $\mathrm{Bu}$ onay kanunu, kanunlar gibi yayınlanmalıdır (m.37/1).

Norveç.- 1814 Norvę Anayasasi ${ }^{43}$, uluslararası andlaşmalan onaylama yetkisini Krala vermiştir (m.26). Kralın bu yetkisi tüm diğer yetkileri gibi karşı-imza kuralına tábidir (m.31). Ancak Anayasaya göre, özel önemdeki konularda ve her halükârda uygulanması için yeni bir kanun veya Storting'in karan gereken andlaşmaların bağlayıı güç kazanabilmeleri için Storting'in rızası gerekir (m.26/2).

Portekiz.- 1976 Portekiz Anayasasına ${ }^{44}$ göre uluslararası andlaşmalan görüşme ve akdetme yetkisi Hükumete aittir (m.200/1-b). Hükamet tarafından yapılmıs uluslararası andlaşmaların Portekiz iç hukukunda uygulanabilmesi ve Portekiz devletini uluslararası alanda bağlayabilmesi için, usûlüne uygun olarak "uygun bulunmuş" ve "onaylanmıs" ve "resmen yayınlanmış" olması gerekir (m.8/2). 1976 Portekiz Anayasası uluslararası andlaşmalan onaylama yetkisini

4017 Haziran 1944 tarihli lzlanda Anayasasının Ingilizce çeviri metni için bkzz: http://www. richmond.edu/ jpjones/confinder/ Iceland2.htm (1.2.2001).

413 Kasım 1946 tarihli Japon Anayasasının Ingilizce çeviri metni için bkz.: http://www.uni-wuerzburg.de/ law/ja00000_html (1.2.2001).

4217 Ekim 1868 tarihli Lüksemburg Anayasasının Fransızca ash için bkz.: http://www.etat.lu/SCL/ CNST0999.PDF (10.3.2001); Ingilizce çeviri metni için bkz.: http://www.uni-wuerzburg.de/law/lu__indx.html (1.2.2001).

4317 Mayıs 1814 tarihli Norvę Anayasasının Ingilizce çeviri metni için bkz.: http://odin.dep.no/ odin/ engelsk/ norway/ system/032005-990424/ index-dok000-b-n-a.html (1.2.2001).

442 Nisan 1976 tarihli Portekiz. Anayasasının Ingilizce çevirisi için bkz.: http://www. parlamento.pt/ constit/ crp_ing.html (1.2.2001). 
ise Cumhurbaşkanına vermektedir (m.138-b). Cumhurbaşkanunun bu yetkisi, karşı-imza kuralına tåbidir (m.143). Cumhurbaşkan ancak usâlünce uygun bulunmus uluslararası andlaşmalan onaylayabilir (m.138-b). 1976 Portekiz Anayasası uluslararası andlaşmaların onaylanması için de iki ayrı sistem öngörmektedir. Anayasanun 166'nd maddesinin "j" bendinde sayılan şu sekiz grup andlaşma, ancak Cumhuriyet Meclisi tarafindan kanunla uygun bulunabilirler: (a) Meclisin münhasır yetki sahasındaki andlaşmalar, (b) Portekiz'in uluslararası organizasyonlara üycliği hakkındaki andlaşmalar, (c) dostluk andlaşmalan, (d) barış andlaşmaları, (e) savunma andlaşmaları, (f) sınur değişikliği andlaşmaları, (g) askeri andlaşmalar, (h) Hükumet tarafından Parlåmentoya sunulan diğer andlaşmalar. Bu sekiz grup andlaşma ancak Cumhuriyet Meclisinin uygun bulması durumunda Cumhurbaşkan tarafından onaylanabilirler. Eğer Anayasa Mahkemesi bir uluslararası andlaşmanun bir hükmünün Anayasaya aykırı olduğuna karar verirse, bu andlaşma ancak Cumhuriyet Meclisinin toplanthya katılan üyelerinin üçte iki çoğunluğunun oyuyla uygun bulunabilir (m.279/4). Toplantya katilan üye sayısı her halükârda üye tamsayısının salt çoğunluğundan fazla olmalıdır (m.279/4). Uygun bulunmalan konusunda Cumhuriyet Meclisinin yetkili olduğu bu sekiz grup andlaşma dışında kalan diğer uluslararası andlaşmalan "uygun bulma" yetkisi Hükumete aittir (m.200/1-c). Hükumet bu andlaşmalan "kararname" ile kullanur (m.200/2). Işte gerek Cumhuriyet Meclisi tarafindan, gerek Hükamet tarafindan uygun bulunmuş andlaşmalar daha sonra Cumhurbaşkan tarafindan onaylanırlar (m.138-b).

Türkiye.- Yukarıdaki ülkelerin anayasaları, parlâmentonun onayına sunulan andlaşmalar saymıs, geri kalan andlaşmaların parlâmentonun onayına intiyaç olmaksızın devlet başkanı tarafından onaylanmasına imkân vermiştir. Türkiye'de ise bunun tersi bir usal izlenmiştir. 1982 Türk Anayasası, parlâmentonun onayına tâbi olan değil, onayına tâbi olmayan andlaşmalan saymış, bunun dışındaki andlaşmaların Cumhurbaşkanı tarafından onaylanabilmesi için Parlâmentonun iznini şart koşmuştur. Dolayısıyla diğer ülkelerde, uluslararası andlaşmaların devlet başkanı tarafından onayı bakımından parlâmentonun izni şart, istisnâ̂, Türkiye'de ise kuraldır. 1982 Türk Anayasasının 90'ıncı maddesinin ikinci fikrasına göre, "ekonomik, ticarî veya teknik ilişkileri düzenleyen ve süresi bir yil aşmayan andlaşmalar, devlet maliyesi bakımından bir yüklenme getirmemek, kişi hallerine ve Türklerin yabancı memleketlerdeki mülkiyet haklarına dokunmamak şarthyla" Cumhurbaşkanunun onayı ve yayını ile yürürlüğe konulabilirler. Keza ayn maddenin üçüncü fikrasına göre, "milletlerarası bir andlaşmaya dayanan uygulama andlaşmalan ile kanunun verdiği yetkiye dayanılarak yapılan ekonomik, ticarî, teknik veya idarî andlaşmaları", Cumhurbaşkan, Türkiye Büyük Millet Meclisinin uygun bulma kanununa ihtiyaci olmadan onaylayarak yürürlüğe koyabilir. Bu andlaşmalar dışında kalan bütün diğer andlaşmalar ve 
keza Türk kanunlarında değişiklik getiren her türlü andlaşmanın Cumhurbaşkan tarafından onaylanabilmesi için, Türkiye Büyük Millet Meclisinin bu andlaşmaların onaylanmasın bir kanunla uygun bulması gerekir (m.90).

Yunanistan.- 1975 Yunan Anayasasına ${ }^{45}$ göre ticaret, vergilendirme, ekonomik işbirliği, uluslararası örgütlere veya birliklere katılma konularında yapılmış andlaşmalar Parlámento tarafindan kabul edilmiş bir kanunla onaylanmadikça yürürlüğe konulamazlar (m.36/2). Uluslararası organizasyonların yetkilerini tanyan andlaşmaların, Parlâmento tarafından onaylanabilmesi için, onay kanununun Parlâmentonun üye tamsayısının üçte ikilik bir çoğunluğuyla kabul edilmesi gerekir (m.36/2). Keza, ulusal egemenliğin kullanılmasına sınırlandırmalar getiren uluslararası andlaşmaların Parlámento tarafından üye tamsayısının salt çoğunluğuyla onaylanması gerekir (m.36/3).

\section{B. KARŞILAŞTIRMA}

Şimdi yukandaki yirmi iki ülkenin uluslararası andlaşmaları onaylama yetkisi bakımından anayasal düzenlemelerinin bir karşılaştırmasını yapalım.

\section{Onay Yetkisinin Verildiği Organlar}

Incelediğimiz anayasalardan sadece birkaçı onay yetkisini doğrudan parlámentolara vermektedir. Diğerleri ise onay yetkisini devlet başkanlarına veya hükametlere vermektedir.

a) Parlâmentolara Verenler.- 1787 Amerika Birleşik Devletleri Federal Anayasası (m.2,b.2,f.2), 1994 Belçika Anayasası (m.167/2) ve 1868 Lüksemburg Anayasası (m.38/1) uluslararası andlaşmalan onaylama yetkisini doğrudan doğruya Parlâmentolara vermektedir.

b) Devlet Başkanlanna Verenler.- Incelediğimiz ülkelerin çoğunluğu uluslararası andlaşmalanı onaylama yetkisini devlet başkanlarına vermektedir. Uluslararası andlaşmalan onaylama yetkisi Almanya'da Cumhurbaşkanına (m.59), Avusturya'da Cumhurbaşkanuna (50), Danimarka'da Krala (bölüm 19), Finlandiya'da Cumhurbaşkanuna (m.93), Fransa'da ise Cumhurbaşkanuna (m.52), Ingiltere'de Taca, Ispanya'da Krala (m.63/2), Israil'de Cumhurbaşkanına (bölüm 11/5), Izlanda'da Cumhurbaşkanuna (m.21), Japonya'da Imparatora (m.73/3, m.7/1), Norveç'te Krala (m.26), Portekiz'de Cumhurbaşkanına (m.200/1-b), Türkiye'de Cumhurbaşkanına (m.104), Yunanistan'da Cumhurbaşkanına (m.36)

459 Haziran 1975 tarihli Yunan Anayasasınun Ingilizce çeviri metni için bkz: http://www.uni-wuerzburg.de/law/gro000_.html (1.2.2001). 
verilmiştir. Amerika Birleşik Devletlerinde ise executive agreements denen andlaşmalan yapma ve onaylama yetkisinin Başkana ait olduğu kabul edilmektedir.

c) Hükûmete Verenler.- Incelediğimiz ülkeler arasında uluslararası andlaşmalan onaylama yetkisi trlanda'da (m.29/4-1), Isveç'te (Bölüm 10, m.2), Isviçre'de (m.184), doğrudan doğruya hükômete verilmiştir. Fransa'da ise, "basit şekildeki andlaşmalar (accords en forme simplifiée)" denilen andlaşmalan (m.52/2) Cumhurbaşkaninun onayı olmadan Hükamet sadece imza ile yürürlüğe koyabilmektedir (m.52/2).

d) Karşı-İmza Kuralı.- Parlâmenter hükamet sistemini benimsemiş ülkelerde, uluslararası andlaşmaları onaylama yetkisi devlet başkanuna verilmiş ise, devlet başkanının bu onay yetkisi karşı-imza kuralına tábi tutulmuştur. 1949 Alman Anayasası (m.58), 1929 Avusturya Anayasası (m.67), 1994 Belçika Anayasası (m.106), 1953 Danimarka Anayasası (bölüm 14), 1999 Finlandiya Anayasası (m.93), 1958 Fransız Anayasası (m.19), Ingiltere (anayasal konvansiyon), 1983 Hollanda Anayasası (m.47), 1978 Ispanyol Anayasası (m.64), 16 Haziran 1964 tarihli Devlet Başkan Hakkında Israil Temel Kanunu (bölüm 11/5), 1947 Italyan Anayasası (m.79), 1944 Izlanda Anayasası (m.19), 1814 Norvec Anayasası (m.31), 1982 Türk Anayasası (m.105) ve 1975 Yunan Anayasası (m.35). Bu ülkelerde devlet başkanları uluslararası andlaşmaları onaylama yetkisini ancak başbakan ve dışişleri bakanının karşı-imzasını alarak kullanabilir. Uluslararası andlaşmaları onaylama yetkisi bakımından karşı-imza kuralının istisnasız bütün parlâmenter ülke anayasalarının tanımı̧ olması, parlâmenter demokrasinin mantiğıyla uyuşum içindedir. Zira, parlâmenter demokrasilerde uluslararası ilişkiler alanında sorumluluk, devlet başkanlarına değil, hükúmetlere aittir. Sorumluluk hükûmetlere ait olduğuna göre, uluslararası andlaşmaları onaylama yetkisinin karşı-imza kuralına tábi olması fevkalåde normaldir.

\section{Parlåmentonun "Uygun Bulması" \artı}

Uluslararası andlaşmalan "onaylama (ratification)" yetkisinin devlet başkanına veya hükûmetlere verildiği ülkelerde, bu onaylama yetkisi, mutlak nitelikte değildir ${ }^{46}$. Bu yetkinin kullanilması, ya bütün andlaşmalar için, yahut belirlenen bazı andlaşmalar için parlâmentonun iznine bağı tutulmuştur. Yani

46 Mutlak monarşilerde istisnasız bütün andlaşmalar münhasıran kralın onayına tâbidir. Mutlak monarşilerde kral, dıs politikanun hakimidir. Andlaşmaları görüşür, imzalar ve onaylar. //rneğin Fransa'da 1814 ve 1830 Sartları bu sistemi benimsemiştir (BARTHIELEMY / DUEZ, 1933: 836). Bu sistemde, parlâmentoların andlaşma yapılması sürecinde herhangi bir yetkisi yoktur. Andlaşmalar yürütme organı tarafından akdedilmekte ve yine yürütme organ tarafından onaylanmaktadır. Bu sistem artık terkedilmiştir. 
devlet başkanları ve hükâmetlerin, uluslararası andlaşmaları onaylayabilmeleri için öncelikle parlåmentonun bu konuda iznini almalan gerekmektedir. Parlâmentolar bu izni, "uygun bulma (approval, approbation)" denilen bir işlem ile vermektedirler. Bazı ülkelerde parlámentonun yaptzğı işleme "onay izni (autorisation de ratification)" ismi de verilmektedir (Örneğin 1958 Fransız Anayasası, m.54). Incelediğimiz anayasalardan bazları istisnasız bütün andlaşmalar için parlâmentonun "uygun bulması" şartın ararken, diğer bazılan bu şartı kendi belirledikleri bazı andlaşmalar için aramaktadır.

a) Bütün Andlaşmalar İçin Parlâmentonun Uygun Bulması Şartını Arayanlar.- Incelediğimiz ülkelerin üçünde, istisnasız bütün andlaşmalarnn onaylanabilmesi için parlâmentonun uygun bulması şartır. 16 Haziran 1964 tarihli Devlet Başkanı Hakkında Israil Temel Kanunu (bölüm 11/5), 1999 Isviçre Anayasası (m.184) ve 1946 Japon Anayasasına (m.73) göre, bütün andlaşmaların onaylanabilmesi için öncelikle parlâmento tarafından uygun bulunmalan gerekmektedir. Keza 1994 Bclçika Anayasası (m.167/2) ve 1868 Lüksemburg Anayasasına (m.38) göre zaten andlaşmaları onaylama yetkisi genel olarak Parlåmentolara aittir. Dolayısıyla incelediğimiz ülkelerin sadece beşinde, onay sürecinde parlâmentolara tanınan yetki, bütün andlaşmalar için geçerlidir. Dolayısıyla bu beş ülkede, uluslararası andlaşmaların onaylanması konusunda parlåmentoların mutlak bir yetkisi vardır.

b) Bazı Andlaşmalar İ̧̧in Parlâmentonun Uygun Bulması Şartını Arayanlar.- Incelediğimiz ülkelerin çoğunluğunda anayasalar bütün andlaşmalar için değil, kendi saptadıklan belirli andlaşmalann devlet başkan veya hükamet tarafindan onaylanmadan önce parlâmentolar tarafindan uygun bulunmasını şart koşmaktadır: Almanya (m.59), Avusturya (m.50), Danimarka (bölüm 19), Finlandiya (bölüm 94/1), Fransa (m.53/1), Ingiltere (konvansiyon), Irlanda (m.29/5), Ispanya (m.94/1), Isvę (bölüm 10, m.2/1), Italya (m.80), Izlanda (m.21), Norvę (m.26/2), Portekiz (m.166-j), Türkiye (m.90/2,3,4) ve Yunanistan (m.36/2).

Anayasaların parlámento tarafından uygun bulunmasın şart koştukları andlaşmalar nelerdir? Bu soruya tam yanıt vermek için her ülkenin kendi anayasasının ilgili maddesine bakmak gerekir. Bu konuda aşağıdaki ekte sunulan tablonun sckizinci sütununa bakılabilir. Çeşitli ülkelerde şu andlaşmalann parlâmentolar tarafından uygun bulunmalan gerektiği gözlemlenmektedir:

aa) Kanunlarda Değişiklik Yapan Andlaşmalar.- Çeşitli anayasalar kanunlarda değişiklik yapan andlaşmaların parlâmentolar tarafından uygun bulunmasınu şart koşmaktadırlar. Bunun nedeni kolayca anlaşılmaktadır. Kanun yapma yetkisi parlâmentoya ait olduğuna göre, yürütme organu, parlâmentonun izni olmadan kanunlarda andlaşma yoluyla değişiklik yapamamalıdır. Bu kural kuvvetler ayrilığı ilkesinin doğal sonucudur. Şu ülkelerde kanunlarda değişiklik 
yapan andlaşmaların onaylanmadan önce parlâmento tarafından uygun bulunması gerekmektedir: Avusturya (m.50), Ingiltere (anayasal konvansiyon), Ispanya (m.94/1), Isveç (bölüm 10, m.2/1), Italya (m.80), Türkiye (m.90/2,3,4). Bazı ülkelerde de, ayn amaçla, kanunlarda değişiklik yapan andlaşmaların değil, daha geniş bir ifadcyle teşrî nitelikteki andlaşmalann veya teşrî nitelikteki hükümlerde değişiklik yapan andlaşmaların veya yasama yetkisi alanına giren andlaşmaların onaylanması için parlâmentonun uygun bulması şart aranmaktadır. Örneğin 1999 Finlandiya Anayasasına göre teşriî nitelikteki andlaşmalann (bölüm 94/1), 1958 Fransız Anayasasına göre teşriî nitelikteki hükümlerde değişiklik yapan andlaşmalann (m.53/1), 1949 Alman Anayasasına göre, federal yasama yetkisi alanuna giren andlaşmaların (m.59), 1976 Portekiz Anayasasına göre Parlâmentonun münhasır yetki sahasındaki andlaşmaların (m.166-j) ve 1814 Norveç Anayasasına göre uygulanması için yeni bir kanun gereken andlaşmaların (m.26/2) onaylanabilmesi için parlâmento tarafından uygun bulunmaları gerekmektedir.

bb) Siyasal Nitelikteki Andlaşmalar.- Bazı anayasalar ise siyasal nitelikteki andlaşmaların devlet başkanı veya hükamet tarafından onaylanmadan önce parlâmento tarafından uygun bulunması şartın getirmektedir. Örneğin 1929 Avusturya Anayasasina (m.50), 1978 Ispanyol Anayasasına (m.94/1) ve 1947 Italyan Anayasasına (m.80) göre siyasal nitelikteki andlaşmaların onaylanabilmesi için parlâmento tarafından uygun bulunması gerekir.

cc) Ülke Sinırlarında Değişikliğe, Ülke Terkine veya Kazanilmasına llişkin Andlaşmalar.- Bazı anayasalar ise ülke terkine veya kazanulmasına veya ülke sınırlarında değişiklik yapılmasına ilişkin andlaşmaların parlâmento tarafından uygun bulunmasını şart koşmaktadır. Örneğin 1953 Danimarka Anayasasına göre ülkeyi genişleten veya daraltan andlaşmalar (bölüm 19); 1958 Fransız Anayasasına göre toprak terki, ilavesi ve değişimi öngören andlaşmalar (m.53/1), 1978 Ispanyol Anayasasına göre devlet ülkesinin bütünlüğüne ilişkin andlaşmalar (m.94/1), 1947 Italyan Anayasasına göre ülke değişimi içeren andlaşmalar (m.80), 1976 Portekiz Anayasasına göre sınur değişikliği andlaşmalan (m.166-j) parlâmento tarafından uygun bulunmalıdırlar. 1944 tzlanda Anayasası ise ülke ve karasuları üzerinde vazgeçme ve irtifak hakkının tanınmasına ilişkin olan andlaşmaların yapılmasın tümden yasaklamaktadır (m.21).

dd) Vergilendirmeye Ilişkin Andlaşmalar veya Devletin Maliyesine Yük Getiren Andlaşmalar.- Bazı anayasalar vergilendirmeye ilişkin andlaşmaların veya devletin maliyesine yük getiren andlaşmalann onaylanmadan önce parlâmento tarafından uygun bulunması şartın aramaktadır. Bu şartın varlık nedeni anlaşılmaktadır. Vergilerin ve kamu harcamaların kanunîliği ilkesinin olduğu bir ülkede, bu alanlarda parlâmentolar yetkilidir. Devlet başkanlarının veya hükametlerin parlâmentoyu uluslararası andlaşma yoluyla aşıp vergi koyması 
veya devlet maliyesine yük getirmesi parlâmentoların malî yetkilerine aykırı olur. Örneğin 1958 Fransız Anayasasına göre devletin maliyesine yük getiren andlaşmalann (m.53/1), 1937 Irlanda Anayasasına göre kamu maliyesine yük getiren andlaşmaların (m.29/5), 1978 Ispanyol Anayasasına göre devlet hazinesine borç yükleyen andlaşmaların (m.94/1), 1947 Italyan Anayasasına göre maliyeye yük getiren andlaşmaların (m.80), 1975 Yunan Anayasasına göre vergilendirmeye ilişkin andlaşmaların (m.36/2) parlâmento tarafından uygun bulunmalan gerekir. Ingiltere'de de vergilendirme ve kamu harcamalanna ilişkin andlaşmaların Parlâmento tarafından teyit edilmesi gerektiği yolunda anayasal konvansiyon vardır (A.C. 326, 347 [1937], HOOD PHILLIPS / JACKSON, 1987: 286 ${ }^{47}$. Türkiye'de ise Anayasanun $90^{\prime \prime n a ~ m a d d e s i n i n ~ i k i n c i ~}$ fikrasından "devlet maliyesi bakımından bir yüklenme" getiren andlaşmaların Türkiye Büyük Millet Meclisi tarafından uygun bulunmadıkça onaylanamayacakları sonucu çıkmaktadır.

ee) Uluslararası Örgütlere lliskkin Andlaşmalar.- Bazı anayasalar (1958 Fransız Anayasası, m.53/1; 1976 Portekiz Anayasası, m.166-j; 1975 Yunan Anayasası, m.36/2), uluslararası örgütlere ilişkin ve özellikle devletin uluslararası örgütlere katılmasın öngören andlaşmaların onaylanmadan önce parlâmento tarafından uygun bulunmasını şart koşmaktadır.

ff) "Önemli Andlaşmalar".- Bazı anayasalar ise parlâmentonun uygun bulmasına bağlı tutulan andlaşmalar arasında "diğer önemli andlaşmaları" saymıştır. Örneğin 1953 Danimarka Anayasasına göre büyük bir öneme sahip diğer andlaşmaların Kral tarafından onaylanabilmesi için Parlâmentonun rızasıın alınması gerckir (bölüm 19/1) 1999 Finlandiya Anayasası da diğer bir şekilde önem arz eden andlaşmaların Parlâmento tarafından uygun bulunması şartını getirmektedir (bölüm 94/1). 1814 Norvę Anayasasına göre de "özel önemdeki konularda" yapılan andlaşmaların Parlâmento tarafından uygun bulunmalan gerekir (m.26/2).

88) Diğer Andlaşmalar.- Çeşitli ülkclerin anayasaları daha birçok tür andlaşmanın Parlâmento tarafından uygun bulunması şartını öngörmektedir. Örneğin, 1958 Fransız Anayasasına göre barış andlaşmalarının, ticaret andlaşmalarının, kişi hallerine ilişkin andlaşmaların parlâmento tarafından uygun bulunması gerekmektedir (m.53/1). 1978 Ispanyol Anayasasına göre askerî nitelikteki andlaşmaların (m.94/1), 1947 Italyan Anayasasına göre tahkime ilişkin andlaşmaların (m.80), 1976 Portekiz Anayasasına göre de dostluk andlaşmalarını, barış andlaşmalarının, savunma anlaşmalarının (m.90/2), 1975 Yunan Anayasasına göre ticaret ve ekonomik işbirliği

47 Bu husus, 1610 tarihli Case of Proclamations ve 1689 tarihli Bill of Rights' in bir sonucudur (HOOD PIIILLIPS /JACKSON, 1987: 286). Zira bu belgelere göre kanunsuz vergi ve kamu harcaması olmaz. 
konularında yapılmış andlaşmaların Parlâmento tarafından uygun bulunması gerekir (m.36/2). 1983 Hollanda Anayasası ise hangi andlaşmaların Parlâmentonun uygun bulmasına tâbi tutulduğunu belirleme yetkisini kanun koyucuya bırakmıştır (m.91/1).

c) Özel Karar Yetersayısı.- Incelediğimiz ülkelerin altısında (ABD, Avusturya, Finlandiya, Hollanda, Portekiz ve Yunanistan) bazı andlaşmaların parlâmento tarafından uygun bulunabilmesi için özel karar yetersayısı ile kabul edilmeleri gerekmektedir:

Amerika Birleşik Devletleri Anayasasına göre, uluslararası andlaşmalar Senatonun üye tamsayısınun üçte ikilik çoğunluğuyla uygun bulunabilirler (b.2, $\mathrm{m} .2, \mathrm{f} .2)$.

1929 Avusturya Anayasasına göre Anayasanın bir hükmünü değiştiren veya Anayasada değişiklik yapan uluslararası andlaşmalar, Nationalratın üye tamsayısının en az salt çoğunluğunun bulunduğu toplantıda üçte iki oy çoğunluğuyla onaylanabilir ( $\mathrm{m} .50 / 3,44 / 1)$.

1999 Finlandiya Anayasasına göre, Anayasaya ilişkin olan veya ulusal sınırlarda değişiklik yapan andlaşmalar Parlâmentoda üçte ikilik oy çoğunluğuyla oylanabilir (bölüm 94/2, 95/2).

1983 Hollanda Anayasasına göre, yasama, yürütme ve yargı yetkilerinin uluslararası kurumlara devrine ilişkin olan andlaşmaların Parlâmento tarafından uygun bulunabilmesi için, Parlâmentonun her iki Meclisi tarafından üçte iki oy çoğunluğu ile kabul edilmesi gerekir (m.92 mucibince m.91/3).

1975 Yunan Anayasasına göre uluslararası organizasyonların yetkilerini tanyyan andlaşmaların, Parlâmento tarafından onaylanabilmesi için, onay kanununun Parlâmentonun üye tamsayısının üçte ikilik bir çoğunluğuyla kabul edilmesi gerekir (m.36/2). Keza, ulusal egemenliğin kullanılmasına sınırlandırmalar getiren uluslararası andlaşmaların Parlâmento tarafından üye tamsayısının salt çoğunluğuyla onaylanması gerekir (m.36/3).

Ayrıca aşağıda göreceğimiz gibi 1976 Portekiz Anayasasına göre Anayasa Mahkemesi tarafından Anayasaya aykın olduğuna karar verilen andlaşmaların onaylanabilmesi için Cumhuriyet Meclisinin toplantıya katılan üyelerinin üçte iki çoğunluğunun oyu gerckir (m.279/4). Toplantıya katılan üye sayısı her halükârda üye tamsayısınn salt çoğunluğundan fazla olmalıdır (m.279/4).

\section{Uluslararası Andlaşmaların Anayasaya Uygunluğu Sorunu ve Çözümü}

Incelediğimiz anayasalardan altısı (1929 Avusturya Anayasası, 1999 Finlandiya Anayasası, 1958 Fransız Anayasası, 1983 Hollanda Anayasası, 1978. Ispanyol Anayasası, 1976 Portekiz Anayasası), bir uluslararası andlaşmanın anayasaya aykın olabileceği ihtimalini öngörerek bu sorunun çözümü için çeşitli kurallar getirmiştir. 
1958 Fransız Anayasasina göre Anayasa Konseyi bir uluslararası andlaşmanın Anayasaya aykırı bir hüküm içerdiğine karar verirse, böyle bir andlaşmanın onaylanmasına, ancak, Anayasa değişikliğinden sonra izin verilebilir (m.54). Anayasa Konseyine bu amaçla, Cumhurbaşkanı, Başbakan, Meclis Başkanları, 60 milletvekili veya 60 senatör başvurabilir (m.54).

1983 Hollanda Anayasasına göre, Anayasaya aykın olan andlaşmaların uygun bulunabilmesi için Parlámentonun her iki Meclisi tarafindan üçte iki oy çoğunluğuyla kabul edilmesi gerekir (m.91/3).

1978 Ispanyol Anayasasına göre Anayasaya aykın hükümler içeren bir uluslararası andlaşmanun onaylanabilmesi için öncelikle Anayasada değişiklik yapılması gerekir (m.95/2). Bir andlaşmanın Anayasaya aykın olup olmadığı konusunda Hükâmet veya meclislerden her biri Anayasa Mahkemesine başurabilir (m.95/2).

1976 Portekiz Anayasasina göre Anayasa Mahkemesinin Anayasaya aykın olduğuna karar verdiği andlaşmaların onaylanabilmesi için, Cumhuriyet Meclisisin toplantıya kathlan üyelerinin üçte iki çoğunluğunun kabul oyu gerekir (m.279/4). Toplantıya katılan üye sayısı her halükårda üye tamsayısının salt çoğunluğundan fazla olmalıdır (m.279/4).

Ayrıca yukarıda gördüğümüz 1929 Avusturya Anayasası ve 1999 Finlandiya Anayasasında da bir uluslararası andlaşmanun anayasaya aykırılı̆̆ sorununun çözümü vardır. Zira, 1929 Avusturya Anayasasına göre, Anayasanın bir hükmünü değiştiren veya Anayasada değişiklik yapan uluslararası andlaşmalar, Nationalrat'ın özel bir karar yetersayısı ile uygun bulunmalıdır (m.50/3 gereğince m.44/1). O halde Avusturya'da Anayasaya aykırı olan bir andlaşma, Anayasanun bir hükmünü değiştiren bir andlaşma olarak yorumlanur. Böyle bir andlaşmanın onaylanabilmesi için Nationalrat tarafından üye tamsayısının en az salt çoğunluğunun bulunduğu toplantıda üçte iki oy çoğunluğuyla uygun bulunması gerekir (m.50/3 gereğince m.44/1).

1999 Finlandiya Anayasası da Anayasada değişiklik yapan andlaşmaların Parlâmentoda üçte ikilik oy çoğunluğuyla oylanabilmesini öngördüğüne göre (bölüm 94/2, 95/2), Finlandiya'da da andlaşmalann Anayasaya aykırılı̆̆ı sorununun çözümü vardır. Anayasaya aykun hükümler içeren bir andlaşma, Anayasada değişiklik yapan bir andlaşma olarak kabul edilir ve parlâmentonun nitelikli çoğunluğuyla onaylanırsa, bu andlaşmanın Anayasaya aykırılığı bakımından bir problem kalmaz.

4. Devlet Başkanları veya Hükûmetler Parlåmentoların Uygun Bulduğu Andlaşmaları Onaylamayı Reddedebilirler mi?

Yukarıda gördüğümüz gibi ülkelerin çoğunluğunda uluslararası andlaşmalan onaylama yetkisi, parlâmentonun uygun bulmasından sonra, 
devlet başkanlarina (Almanya, Avusturya, Danimarka, Fransa, Ingiltere, Ispanya, Israil, Italya, Izlanda, Japonya, Norveç, Portekiz, Türkiye, Yunanistan) veya hükametlere (Irlanda, Isviçre, Isvę) aittir. Acaba, bu ülkelerde, devlet başkanları veya hükumetler, parlâmentoların uygun buldukları uluslararası andlaşmalan onaylamayı reddedebilirler mi?

Kanumızca bu soruya olumlu yant verilebilir. Devlet başkanları veya hükumetler parlâmentolann onaylanmasın uygun bulduklan andlaşmalan onaylamak zorunda değildir. Zira, bu sistemde, bir andlaşmanun onaylanup onaylanmaması parlâmentonun "uygun bulmasına (apprabation, appraval)" bağh olsa da, "onay (ratification)" işlemi, hukukŝ niteliği itibarıyla, parlâmentonun değil, devlet başkanının bir işlemidir (BARTHÉLEMY / DUEZ, 1933: 834). Bu sistemde, parlâmentonun "uygun bulma" iradesi, devlet başkanınun veya hükumetin onay iradesinin bir "gerekli şart"dır; ama "yeterli şartı" değildir. Devlet başkanı veya hükûmet hukukîlik veya yerindelik düşüncesiyle andlaşmayı onaylamaktan son anda vazgeşcbilir. Zira andlaşma cicvletin uluslararası sorumluluğunu doğuracaktır. Uluslararası politikada değişen koşullar bakımından devlet başkanı veya hükûmet andlaşmayla ülkenin bağlanmasını yerinde görmeyebilir. Dı̊ politika alanında parlâmentoların yetkisi nihaî ve mutlak yetki değildir. Bu yetki esas itibarıyla yürütme organına aittir. Parlâmentonun sadece bir denetleme yetkisi vardır.

Şüphesiz, parlâmenter hükâmet sistemine sahip bir ülkede, devlet başkanı parlâmentonun uygun bulduğu andlaşmayı onaylamayı kendi istcğiyle değil, hükumetin isteğiyle reddedebilir. Daha doğrusu, bir parlâmenter demokraside onaylama işlemi, başbakan ve ilgili bakanen karşı-imzası ile gerçekleşeceğine göre, başbakan veya ilgili bakanın karşı-imzalarını koymayı reddetmeleri durumunda, parlâmentonun onaylanmasını uygun bulduğu bir andlaşma onaylanmayacaktır.

Yürürlüğe Girme.- Onaylanan andlaşmaların yürürlüğe girebilmesi için öncelikle taraf devletler arasında "onay belgelerinin değişimi (exchange of the instruments of ratification, échange des instruments de ratification)" gereklidir (CARREAU, 1988: 116; BROWNLIE, 1996: 607; PAZARCI, i998: 133). Parlâmenter hükûmet sistemlerinde, bu "onay belgesi" de devlet başkanının imzasın ve başbakan ve dışş̧leri bakanun karşı-imzasını taşır (PACTET, 1994: 504). Andlaşma kendi metninde daha sonraki bir tarihi öngörmüyorsa, son onay belgesinin değişimi tarihinde uluslararası hukuk bakımından yürürlüğe girdiği kabul edilir (PAZARCI, 1998: 133).

Yayın.- Onaylanan andlaşmanın, onaylayan devletin kendi iç hukukunda yürürlüğe girmesi için de, her devletin kendi iç hukuku tarafından öngörülen "ilân (proclamation)" ve "yayın (publication)" gibi işlemlerin de yapılması gereklidir (PAZARCI, 1998: 136-137; GREWE / RUIZ FABRI, 1995: 105). Bazı anayasalar yayın zorunluluğunu açıkça öngörmüşlerdir: 1929 Avusturya 
Anayasası andlaşmalarn "Federal Şansölye (Bundeskanzler)" tarafından "Federal Kanun Gazetesi (Bundesgesetzblatt)"nde yayınlanmasın öngörmektedir (m.49/1). 1978 Ispanyol Anayasası da uluslararası andlaşmaların Ispanyolca olarak resmen yayınlanmasın öngörmektedir (m.96/1). 1868 Lüksemburg Anayasası da uluslararası andlaşmaları onaylayan onay kanunlarınun kanunlar gibi yayınlanmasın öngörmektedir (m.37/1). 1976 Portekiz Anayasasına göre de usalüne göre kabul edilmiş ve onaylanmiş uluslararası andlaşmaların Portekiz iç hukukunda uygulanabilmesi ve Portekiz devletini uluslararası alanda bağlayabilmesi için resmen yayınlanmıs olması şartın aramaktadır (m.8/2).

Yayınlanıp yürürlüğe giren andlaşmalann son olarak, Birleşmiş Milletler Sekreterliğine tescil ettirilmesi gerekir. Bundaki amaç, devletlerin "gizli andlaşma (secret treaty, traité secret)" yapmalarını önlemektir (PAZARCI, 1998: 138-140). Bazı anayasalar gizli andlaşma yapma yasağını açıkça öngörmüşlerdir: Örneğin 1868 Lüksemburg Anayasasının 37'nci maddesinin üçüncü fkkrası "gizli andlaşmalar lağvedilmiştir" demektedir. 1975 Yunan Anayasası ise, bir andlaşmanun gizli maddelerinin yayınlanmış maddelerini hiçbir durumda geçersiz hale getiremeyeceğini hükme bağlamaktadır (m.36/3).

\section{SONUG}

Yukarıda incelediğimiz yirmi iki ülkede, uluslararası andlaşma akdetme yetkisi yasama organlarına değil, yürütme organlarına ait bir yetkidir. Yürütme organun içinde bu yetki, bazı ülkelerde (Almanya, Belçika, Danimarka, Finlandiya, Fransa, Ingiltere, Izlanda, Lüksemburg, Norvec ve Yunanistan) devlet başkanuna, diğer bazı ülkelerde (Irlanda, Isvȩ̣, Isviçre, Japonya, Portekiz) ise hükamete verilmiştir. Akdetme yetkisinin devlet başkanuna verildiği istisnasız bütün ülkelerde bu yetki, karşı-imza kuralına tâbi tutulmuştur.

Incelediğimiz ülkelerden sadece üçü ( $A B D$, Belçika ve Lüksemburg) onay yetkisini parlâmentolara, on alțsı (Almanya, Avusturya, Danimarka, Finlandiya, Fransa, Hollanda, Ingiltere, Ispanya, Israil, Italya, Izlanda, Japonya, Norveç, Portekiz, Türkiye, Yunanistan) devlet başkanlarına ve üçü (Irlanda, Isviçre, Isvec) hükametlere vermektedir. Onay yetkisinin devlet başkanına verildiği ülkelerin hepsinde devlet başkanının bu yetkisi karşı-imza kuralına tábi tutulmuştur. Onay yetkisinin devlet başkanlarına veya hükametlere verildiği ülkelerin hepsinde, bu yetkinin kullanılabilmesi, uluslararası andlaşmanun parlâmento tarafından "uygun bulunması" şartına bağlanmıştır. Üç ülkede (İrail, Isviçre Japonya) parlâmento tarafından uygun bulunma şartı bütün andlaşmalar için aranırken, çoğunluğu teşkil eden diğer ülkelerde (Almanya, Avusturya, Danimarka, Finlandiya, Fransa, Ingiltere Irlanda, Ispanya, Isvec, Italya, Izlanda, Norvec, Portekiz, Türkiye ve Yunanistan) bütün 
andlaşmalar için değil, bazı andlaşmalar için parlâmentonun uygun bulması şart aranmaktadır.

Bazı ülkelerde (Amerika Birleşik Devletleri, Avusturya, Finlandiya, Hollanda, Portekiz ve Yunanistan) parlâmentonun bazı andlaşmalan uygun bulabilmesi için $2 / 3$ gibi özel karar yetersayısı öngörülmüştür. Diğer bazı ülkelerde ise anayasaya aykun andlaşmaların onaylanabilmesi için ya Anayasada değişiklik yapılması (Fransa, Ispanya) ya da anayasaya aykırı olan uluslararası andlaşmanun parlâmentonun nitelikli çoğunluğu tarafından kabul edilmesi (Hollanda, Portekiz) şart getirilmiştir. 


\begin{tabular}{|c|c|c|c|c|c|c|c|c|}
\hline \multicolumn{9}{|c|}{ TABLO : ULUSLARARASI ANDLAŞMALARI AKDETME VE ONAYLAMA YETKISİ } \\
\hline \multirow[b]{2}{*}{ ÜLKELER } & \multirow[b]{2}{*}{ AY } & \multirow[b]{2}{*}{$\begin{array}{c}\text { MAD } \\
\text { DE }\end{array}$} & \multicolumn{2}{|c|}{ AKDETME } & \multicolumn{4}{|c|}{ ONA: } \\
\hline & & & $\begin{array}{l}\text { Akdetme } \\
\text { Yet }\end{array}$ & $\begin{array}{l}\text { Karș:- } \\
\text { Imza }\end{array}$ & $\begin{array}{l}\text { Onay } \\
\text { Yetkisi }\end{array}$ & $\begin{array}{c}\text { Karş- } \\
\text { Imza }\end{array}$ & Paslàmento Tara findan Uygun Bulunma Sartı & $\begin{array}{c}\text { Özel ÇoğunlukJ } \\
\text { Anayasaya Aykınlık }\end{array}$ \\
\hline$\overline{\text { A.B.D. }}$ & 1787 & $\mathrm{~m} .2 / 2$ & Başkan & Tek Başina & Senato & & Bütün andlaşmalar(Executive Agreement'lar Hariç) & $2 / 3$ Çoğunluk \\
\hline Almanya & 1949 & m.59 & $\begin{array}{l}\text { Cumhur- } \\
\text { başkanı }\end{array}$ & $\begin{array}{l}\text { Karşı- } \\
\text { Imzayla }\end{array}$ & 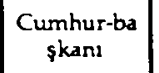 & $\begin{array}{c}\text { Karşı- } \\
\text { Imzayla }\end{array}$ & $\begin{array}{l}\text { Dhş Diskilerini Düzenleyen, (2) Federal Yasama } \\
\text { Yetkisi Ala una Giren Andlaşmalar }\end{array}$ & \\
\hline Avusturya & 1929 & $\mathrm{~m} .50$ & & & $\begin{array}{c}\text { Cumhur-ba } \\
\text { skanı }\end{array}$ & $\begin{array}{c}\text { Karşı- } \\
\text { Imzayla } \\
\text { (m.67) }\end{array}$ & $\begin{array}{l}\text { (1) Siyasal Andlaşmalar, (2) Mevcut Kanunlarda } \\
\text { Değişiklik Yapan Andlaşmalar }\end{array}$ & $\begin{array}{c}\text { Anayasada Değisikllik Yapan } \\
\text { Andl.: } 2 / 3 \mathrm{Oy}+1 / 2 \text { Cyeler } \\
\text { (m.50/3, m.44/1). }\end{array}$ \\
\hline Belçika & 1994 & $\begin{array}{c}\mathrm{m} .167 \\
/ 2\end{array}$ & Kral & $\begin{array}{c}\text { Karș-Imz. } \\
(\mathrm{m} .106)\end{array}$ & $\begin{array}{l}\text { Parlá- } \\
\text { mento }\end{array}$ & & Bütün Andlaşmalar & \\
\hline Danimarka & 1953 & $\begin{array}{c}\text { sek.. } \\
19\end{array}$ & Kral & $\begin{array}{l}\text { Karsi-1mz. } \\
(\mathrm{m} .106)\end{array}$ & Kral & $\begin{array}{c}\text { Karş1- } \\
\text { Imzayla }\end{array}$ & $\begin{array}{l}\text { (1) Cikeyi Gerisleten veya Daraltan Andlasmalar; } \\
\text { (2) Büyük Bir Oneme Sahip Diğer Andlaşmalar }\end{array}$ & \\
\hline Finlandiya & 1999 & $\begin{array}{l}\mathrm{m} .93 \\
94,95\end{array}$ & $\begin{array}{l}\text { Cumhur- } \\
\text { başkanı }\end{array}$ & $\begin{array}{l}\text { Hükümet ile } \\
\text { Işbirliği } \\
\text { Halinde }\end{array}$ & $\begin{array}{l}\text { Cumhur- } \\
\text { baskan1 } \\
\text { (sek. 95) }\end{array}$ & $\begin{array}{c}\text { Karş1 } \\
\text { Imzayla } \\
(\mathrm{m} .58)\end{array}$ & $\begin{array}{l}\text { (1) Teşrii Nitelikte Andlasmalar; (2) Diğer Ónemli } \\
\text { Andlasmalar (Sek } 93,94 / 1 \text { ). }\end{array}$ & $\begin{array}{l}\text { Anayasaya biskin veya Ulusal } \\
\text { Sinurlarda Değisikiklik Yapan } \\
\text { Andlaşmalar. } 2 / 3 \text { Coğunluk } \\
\text { (Sek. } 94 / 2,95 / 2) \text {. }\end{array}$ \\
\hline Fransa & 1958 & \begin{tabular}{|l|}
$\mathrm{m}$. \\
53,54 \\
53,54
\end{tabular} & \begin{tabular}{|c|} 
Cumhurbaş \\
kanı; Basit \\
Şekilde \\
Anlaşm: \\
Hükümet
\end{tabular} & $\begin{array}{l}\text { Karsi- } \\
\text { Impayld } \\
\text { (m. 19) }\end{array}$ & \begin{tabular}{|l|} 
Cumhurbas \\
kani; Basit \\
Sckilde \\
Anlaşm: \\
Hükümet
\end{tabular} & $\begin{array}{c}\text { Karşı- } \\
\text { Imzayla } \\
\text { (m. 19) }\end{array}$ & 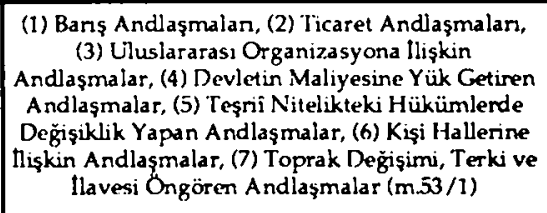 & $\begin{array}{c}\text { Anayasa Konseyi Bir } \\
\text { Andlaşmanin Anayasaya } \\
\text { Aykur Olduğ gna Karar Verirse } \\
\text { Anayasa Değisiklikig̈ Gerekir } \\
\text { (m.54). }\end{array}$ \\
\hline Hollanda & 1983 & $\begin{array}{c}\text { m. } 91 \\
92\end{array}$ & & & Kral & $\begin{array}{l}\text { Karşs- } \\
\text { Imzayla } \\
\text { (m. 47) }\end{array}$ & $\begin{array}{l}\text { Kanunla Belirlenecek Olan Andlaşmalannn } \\
\text { Dhşında Kalan Andlaşmalar (m. 91/1) }\end{array}$ & $\begin{array}{l}\text { (1) Anayasaya Ayken Olan } \\
\text { Andlaşmalar (m.91/3) ve (2) } \\
\text { Yasama, Yürütme ve Yarg1 } \\
\text { Yetkilerinin Uluslararası } \\
\text { Kurumlara Devrine Iliskin } \\
\text { Andlaşmalar (m.92): } 2 / 3 \text { Ço }\end{array}$ \\
\hline
\end{tabular}




\begin{tabular}{|c|c|c|c|c|c|c|c|c|}
\hline \multicolumn{9}{|c|}{ TABLONUN DEVAMI: 2 (ULUSLARARASI ANDLAŞMALARI AKDETME VE ONAYLAMA YETKISI) } \\
\hline ÜLKELER & AY & $\underset{\mathrm{DE}}{\mathrm{MAD}}$ & $\begin{array}{l}\text { Akdetme } \\
\text { Yet. }\end{array}$ & $\begin{array}{l}\text { Kars1- } \\
\text { Imza }\end{array}$ & $\begin{array}{l}\text { Onay } \\
\text { Yetkisi }\end{array}$ & $\begin{array}{l}\text { Karş1- } \\
\text { İmza }\end{array}$ & Parlamento Tarafindan Uygun Bulunma Sartı & $\begin{array}{c}\text { Özel Çoğunluk } \\
\text { Anayasaya Aykurilık }\end{array}$ \\
\hline Ingiltere & $\begin{array}{c}\text { Yaz1- } \\
\text { s12 }\end{array}$ & $\begin{array}{c}\text { Conve } \\
\text { ntion }\end{array}$ & Kraliçe & $\begin{array}{l}\text { Karsi- } \\
\text { Imzayla }\end{array}$ & Kraliçe & $\begin{array}{l}\text { Karşı: } \\
\text { Imzayla }\end{array}$ & $\begin{array}{c}\text { (1) Parlàmento Tarafindan Teyid Edilmesini Öngören } \\
\text { Andlaşmalar; (2) Ingiliz Hukukunda Değisisiklik Getiren } \\
\text { Andlaşmalar; (3) Vergilendirme ve Kamu Harcamalanna } \\
\text { Ilişkin Andlaşmalar, (4) Özel Haklara Dokunan } \\
\text { Andlaşmalar. }\end{array}$ & \\
\hline Lrlanda & 1937 & $\underset{5}{\mathrm{~m} \cdot 29 /}$ & Hüküm. & & Hüküm & & $\begin{array}{c}\text { Kamu Maliyesine Yük Getiren Andlaşmalar (Tekrik Ve } \\
\text { Idari Nitelikteki Andlaşmaların Parlàmentoya } \\
\text { Sunulmalan Gerekli Değildir (m.29/5-3). }\end{array}$ & \\
\hline İspanya & 1978 & $\begin{array}{c}\text { m. 63/ } \\
2\end{array}$ & & & Kral & $\begin{array}{l}\text { Karşı- } \\
\text { Imzaya } \\
(\mathrm{m} .64)\end{array}$ & $\begin{array}{l}\text { (1) Siyasal Nitelikteki Andlaşmalar, (2) Askeri Nitelikteki } \\
\text { Andlaşmalar ve Sözleşmeler, (3) Devlet Cilkesinin } \\
\text { Bütünlüğ̈̈̈ne veya Birinci Başlıkta Düzenlenen Temel Hak } \\
\text { ve Odevlere Dokunan Andlaşmalar, (4) Devlet Hazinesine } \\
\text { Borç Yükleyen Andlaşmalar, (5) Bir Kanunda Değisiklik } \\
\text { Yapan veya Hga Eden Andlaşmalar veya Uygulanmass } \\
\text { lçin Teşri Tedbirler Cerektiren Andlaşmalar (m.94/1). }\end{array}$ & $\begin{array}{l}\text { Anayasa Mahkemesinin } \\
\text { Anayasaya Aykun Olduğu- } \\
\text { na Karar Verdiği Andlas } \\
\text { maların Onaylanabilmesi } \\
\text { lọin Anayasada Değisikiklik } \\
\text { Yapulması Gerekir } \\
\text { (m.95/2). }\end{array}$ \\
\hline Issail & 1964 & $\begin{array}{c}\text { Sek. } 1 \\
1 / 4\end{array}$ & & & $\begin{array}{l}\text { Cumbur- } \\
\text { başkanı }\end{array}$ & $\begin{array}{l}\text { Kars-lm } \\
\text { (sek. 12) }\end{array}$ & Bütün Andlaşmalar & \\
\hline lsves & 1975 & $\begin{array}{c}\text { Bölüm } \\
10, \\
\text { m. 1-2 }\end{array}$ & Hükũmet & & Hükúmet & & $\begin{array}{l}\text { (1) Bir Kanunda Değişiklik Yapan veya Kanunu Ilga Eden } \\
\text { veya Yeri Bir Kanun Cikanlmasın Öngören Andlaşmalas, } \\
\text { (2) Büyük Bir Öneme Sahip Andlaşmalar }\end{array}$ & \\
\hline Ísviçre & 1999 & m.184 & Fed. Hük. & & Fed. Hük. & & Bütün Andlaşmalar & \\
\hline Italya & 1947 & $\begin{array}{c}\mathrm{m} .87 \\
80\end{array}$ & & & $\begin{array}{l}\text { Cumbur- } \\
\text { baskanı }\end{array}$ & $\begin{array}{l}\text { Kars:- } \\
\text { Imzayla } \\
(\mathrm{m} .79)\end{array}$ & $\begin{array}{l}\text { (1) Siyasal Nitelikteki Andlaşmalar, (2) Tahkim veya Adli } \\
\text { Düzenleme Andlaşmalar, (3) Cinke Değişimi lçeren } \\
\text { Andlaşmalar, (4) Maliyeye Yük Getiren Andlaşmalar,-(5) } \\
\text { Kanunlarda Değişiklik Ongören Andlaşmalar (m.80). }\end{array}$ & \\
\hline İlanda & 1944 & m. 21 & $\begin{array}{l}\text { Cumhur- } \\
\text { başkanı }\end{array}$ & $\begin{array}{l}\text { Karş1- } \\
\text { Imzayla } \\
(\mathrm{m} .19)\end{array}$ & $\begin{array}{l}\text { Cumhur- } \\
\text { başkanı }\end{array}$ & $\begin{array}{l}\text { Karş- } \\
\text { Imzayla } \\
(\mathrm{m} .19)\end{array}$ & $\begin{array}{c}\text { Su Andlaşmalann Yapilması Yasaktur: (1) Ulke veya } \\
\text { Karasulan Uzerinde Vazgeçme veya Irtifak Tanımasına } \\
\text { lişkin Arlaşmalar, (2) Devlet Sisteminde Değişiklik } \\
\text { Ongören Andlaşmalar (m.21) }\end{array}$ & \\
\hline
\end{tabular}

(TABLO DEVAM EDIYOR) 
TABLONUN DEVAMI: 3 (ULUSLARARASI ANDLAŞMALARI AKDETME VE ONAYLAMA YETKISh)

\begin{tabular}{|c|c|c|c|c|c|c|c|c|}
\hline OLKELER & AY & $\begin{array}{c}\text { MAD } \\
\text { DE }\end{array}$ & $\begin{array}{l}\text { Akdetme } \\
\text { Yet. }\end{array}$ & $\begin{array}{l}\text { Karpi- } \\
\operatorname{lm} x a\end{array}$ & $\begin{array}{c}\text { Onay } \\
\text { Yetkisi }\end{array}$ & $\begin{array}{l}\text { Karpi- } \\
\operatorname{Imza}\end{array}$ & Parlàmento Tarafindan Uygun Bu'unma Sart & $\begin{array}{c}\text { Ozel Cogunlubl } \\
\text { Anayasaya Aykınlık }\end{array}$ \\
\hline Japonya & 1946 & $\mathrm{~m} .73 / 3$ & Hükûm. & & Imparat & $\begin{array}{l}\text { Hükûm. } \\
(\mathrm{m} .7 / 1)\end{array}$ & Bütün Andlaşmalar & \\
\hline Lüksemburg & 1868 & m. 38 & $\begin{array}{l}\text { Grand } \\
\text { Dük }\end{array}$ & $\begin{array}{c}\text { Kars-lmz } \\
(\mathrm{m} .45)\end{array}$ & Parläm. & & Bütün Andlaşmalar & \\
\hline Norves & 1814 & m. 26 & Kral & $\begin{array}{l}\text { Karsi- } \\
\text { Imzayla } \\
(\mathrm{m} .31)\end{array}$ & Kral & & $\begin{array}{l}\text { (1) Ozel Onemdeki Konularda, (2) Her Halükânda } \\
\text { Uygulanmasi Iọin Yeni Bir Kanun Gereken Andlaşmalar } \\
\text { (m.26/2). }\end{array}$ & \\
\hline Portekiz & 1976 & $\underset{1-b}{m \cdot 200 /}$ & Hükûmet & & $\begin{array}{l}\text { Cumhur- } \\
\text { başkans } \\
\text { (m.138 } \\
\text { /b) }\end{array}$ & $\begin{array}{l}\text { Karsi- } \\
\text { Imzayla } \\
\text { (m. 143) }\end{array}$ & 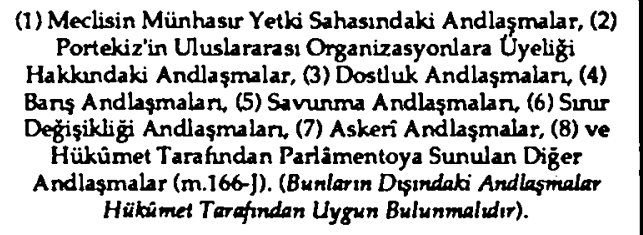 & 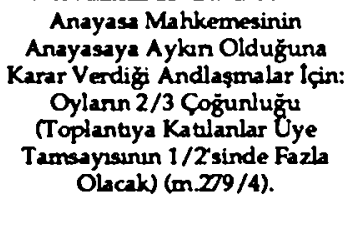 \\
\hline Türkiye & 1982 & $\begin{array}{c}\text { m. } 90 \\
104\end{array}$ & & & $\begin{array}{l}\text { Cumhur- } \\
\text { baskana }\end{array}$ & $\begin{array}{l}\text { Karş- } \\
\text { Imzayla } \\
\text { (m. 105) }\end{array}$ & 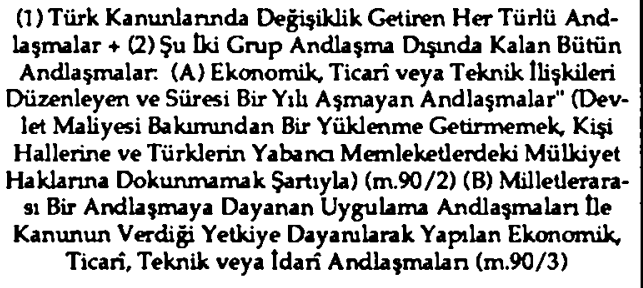 & \\
\hline Yunanislan & 1975 & m. 36 & $\begin{array}{l}\text { Cumhur } \\
\text { baskanu }\end{array}$ & $\begin{array}{l}\text { Karş:- } \\
\text { Imzayla } \\
(\mathrm{m} .35)\end{array}$ & $\begin{array}{l}\text { Cumhur- } \\
\text { başkanı }\end{array}$ & $\begin{array}{l}\text { Karsi- } \\
\text { Imzayla } \\
\text { (m. 35) }\end{array}$ & $\begin{array}{l}\text { (1) Ticaret, (2) Vergilendirme, (3) Ekonomik Işbirliği, (4) } \\
\text { Uluslararası Orgütlere veya Birliklere Katima Konula nnda } \\
\text { Yapilmus Andlaşmalar }\end{array}$ & 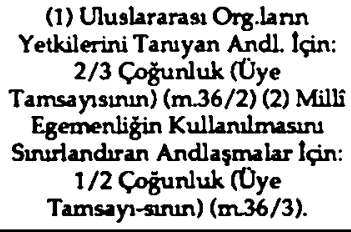 \\
\hline
\end{tabular}




\section{Kaynaklar}

\section{Anayasalar}

A.B.D.: 17 Eylü 1787 Tarihli Amerika Birleşik Devketler Federal Anayasası (Inglizce Asli): http://www.constltution. org/ constit.htm (1.2.2001).

Almanya: 23 Mayis 1949 Torihli Almon Anayasasi (Ingilizce fevirsi): hatp://mmw.unl-wuerzburg.de/low/ gm00000_html (1.2.2001).

Anusturya: 1929 Avusturya Anayasası (Bundes.Verfassungsgesetz in der Fassung von 1929) (Ingilizce Cevirisi): http://www.uni-wuerzbung.de/ law/as00000_html (1.2.2001).

Belęlka: 17 Şubat 1994 Tarihll Belçlka Anayasası (Fransuca Asli): hutp://www.senate.be/ senbeldocs/ constiturion/ const_fr.html (1.2.2001); Ingllizce Cevirisi: hatp://www.unl-wuerzburg.de/law/ be00000_.html. (1.2.2001).

Danlmarka: 5 Haziran 1953 Tarihli Danimorka Anayasası: hup://www.unj-wuerzburg.de/ law/ do00000_html (1.2.2001).

Finlandlya: II Haziran 1999 Tarihli Finlandlya Anayasası (Ingilizce Cevirlsi): htup://www.om.fi/ constitution/ $3340 . \mathrm{htm}(1.2 .2001)$.

Fransa: 4 Ekim 1958 Tarihli Fransiz Anayasası (Fransizca Asli): hup://www.legifrance. gouv.fr/ html/frame_ constiturtion.htm (1.2.2001). Ingillzce Sevirisl: http://www.assemblee-nationale.fr/ 8/8ab.htm (1.2.2001).

Hollanda: 17 Şubat 1983 Tarihll Hollanda Anayasası (Ingilizce Çevirisi): hutp://www.unl-wuerzburg.de/ low/nl00000_.html (1.2.2001).

Irlanda: 1 Temmuz 1937 Torihli Irlonda Anayosasi (Ingilizce Asli): hatp://www.math.tcd.le/pub/ Constitution.html (1.2.2001).

Ispanya: 27 Aralik 1978 Torihll lspanyol Anayososı (Ingllizce Sevirlsl): http://www.unl-wuerzburg.de/law/ sp00000_ heml (1.2.2001). Ispenyolco Asli: http://www.lgsap.map.es/docs/cla/dlspo/ constitu.htm

Israll: 16 Haziran 1964 Tarlhli Devlet Başkanı Hokkinda Israll Temel Kanunu (Basic Law: The President of the Slate) (Ingllizce Cevirisl): http://www.unj-muerburg.de/law/is_Indx.html (1.2.2001).

lsveç: 1 Ocak 1975 Torihli Isvę Anayasasi (Ingilizce Cevirisi): hutp://www.unl-wuerzburg.de/law/ sw00000_html (1.2.2001).

Isviçre: 14 Nisan 1999 Tarihll Isviçre Anayasası (Fronsizco Asli); http://www.admin.ch/ ch/l/rs/101/ Index.html (1.2.2001); Ingillize Cevirisi: http://www.unl-wuerzburg.de/ low/sz00000_html (1.2.2001).

Halya: 27 Aralik 1947 Tarihil thalyan Anayasası (lualyanco Ash): http://www.polazzorhigl.it/ sez_ costltuzlone.html (1.2.2001); Inglizce Cevirisi: http://www.uni-wuerzburg.de/ law/it00000_html (1.2.2001).

Izlanda: 17 Haziran 1944 Torihli Izlanda Anayasası (Ingilizce Cevirlsi): hatp://www. richmond.edu/Jpjones/confinder/ Iceland2.hum (1.2.2001).

Japonya: 3 Kasim 1946 Tarihli Japon Anayasası (Inglilize Cevirisi): hup://www.uni-wuerzburg.de/ law/Ja00000_html (1.2.2001).

Loksemburg: 17 Ekim 1868 Torihll Lüksemburg Anayasosi (Fransizco Asli) hup://www.etat.lu/ SCL/CNSTO999.PDF (10.3.2001); (Ingllize Cevirisl): http://www.unl-wuerzburg.de/low/lu_ Indx.html (1.2.2001).

Morves: 17 Mayıs 1814 Tarlhll Norveç Anayasası (Ingilizce Cevirisl): http://odin.dep.no/ odin/ engelsk/ norway/ system/032005-990424/index-dok000-b-n-a.html (1.2.2001). 
Portekjz: 2 Nisan 1976 Torihli Portekiz Anayasası (Ingilizce Cevirisi): http://www. porlamento.pt/ constit/crp_ling.html (1.2.2001). Porteklzce Asli: hup://www.ceo. ucp.pt/lel/const/constind.htm

Tarklye: 7 Kasım 1982 Tarihli Türkjye Cumhurlyed Anayasası: Resmi Gazete, 9.11.1982, Sayı 17863 Mükerrer, Düstur. Beşincl Tertjp. CIt 22, s.3.

Yunanistan: 9 Haziran 1975 Tarihil Yunan Anayasası (Ingilizce Cevirisi): http://www. hri.org/MFA/ syntagma/artcl50.html (1.2.2001); hap://www.unl-wue rburg.de/ law/gr0000_html (1.2.2001).

Dünyo ulkelerinin anayasa metinlerinln Ingilizce çevirilerine șu $\mathrm{ikl}$ siteden ulaşılabilir:

"ICL: Intemational Constitutional Low", http://www.und-wnerzburg.de/law/ (Bu site A. Tschentscher tarafsndan yōnetilmektedir).

'Constitution Finder", http://www.rlchmond.edu/-jpjones/confinder/const/html (Bu site Richmond Oniversitesi profesōrlerinden John Paul Jones tarafından yōnetilmektedir).

\section{Kitaplar}

AUTEXIER. Christian (1997), Introduction au droit public allemand (Paris: PUF).

BARTHÉLEMY, Joseph / DUEZ, Paul (1933). Traité de droil conslitutionnel (Paris: Dalloz).

BARTHOLOMEW, Paul C. (1970), Ruling American Constitutional Law (New Jersey: Littlefield. Adams $\varepsilon$ Company)(Cilt I).

BROWNLE, Ian (1996), Principles of Public Intemational Law (Oxford: Clarendon Press).

CARREAU, Dominique (1988), Droit intemational (Paris, Pedone).

CHAGNOLAUD, Dominique (1999). Droit constitutionnel contemporain (Paris: Sirey).

CRONIN, Thomos E. (1980). The State of the Presidency (Boston: Little, Brown and Company) (Ikinci Baski).

DE SMTH. S.A. / BRAZIER, Rodney (1989), Constitutional and Administrative Law (London: Penguin Books) (Altunci Baskı).

DuGUIT, Léon (1924). Traitè de droit constitulionnel (Paris: Ancienne librairie fontemoing) (Ikinci Baskı, Cilt IV).

FAVOREU, Louis el al. (1998). Droit constitutionnel (Paris: Dalloz).

GICOUEL, Jean (1999), Droil constilutionnel et institulions politiques (Poris: Montchrestien) (Onaltunc1 Baski).

GREWE, Constance / RUIZ FABRI. Hèlène (1995), Droits constitutionnels européennes (Paris: PUF).

HOOD PHILUPS, O. / JACKSON. Paul (1987). Constitutional and Administrative Law (London: Sweet $\varepsilon$ Maxwell) (Yedinci Boskı).

JACKSON. Vicki V. / TUSHNET, Mark (1999). Comparative Constilutional Law (New York: Foundation Press).

LAVROFF, Dmitri Georges (1995), Le dmit constilutionnel de la Ve République (Paris: Dalloz).

UJPHART, Arend (Tarihsiz). Cağdas Demokrasiler (Ankara: Yetkin Yayınları) (Cev. Ergun Ozbudun ve Ersin Onulduran).

MASON, Alpheus Thomas / BEANEY. William M. (1964). American Constitutionnal Law: Introductory Essays and Selected Cases (New Jersey: Prentice - Hall) (Üçûncũ Baskı).

MIRKINE.GUETZEVITCH, B. (1933), Droit constitutionnel intemational (Paris: Librairie du Recueil Sirey). 
NOWAK, John E: / ROTUNDA. Ronald D. / YOUMG. J. Nelson (1978), Handbook on Constitulional Law (St. Paul. Minn.: West Publishing Co.)

PACTET, Plerre (1994), Institutions politiques.Droil constitutionnel (Parls: Masson) (Onūçūncū Baski).

PAZARCI, Hüseyin (1998). Uluslararasi Hukuk Derslen (Ankara: Turhan Kitabevi) (Yedincl Boskı).

TRIBE, Laurence H. (2000), American Constitutional Law (New York: Foundation Press) (Cilt I).

WGNY, Pierre (1952), Droit constitutionnel: principes et drait positir (Bruxelles: Bruylant).

ZOUER, Elisabeth (1999), Droit constitutionnel (Paris: PUF). 